\title{
PENAFSIRAN/INTERPRETASI IMPLEMENTASI KEBIJAKAN PEMUNGUTAN PAJAK BUMI DAN BANGUNAN
}

\author{
Petrus Atong \\ Fakultas Ilmu Sosial dan Ilmu Politik Universitas Kapuas
}

\begin{abstract}
Abstrak:. Penelitian penafsiran implementasi kebijakan pemungutan pajak bumi dan bangunan di wilayah Kecamatan Sintang, menjelaskan penyebab tidak tercapainya target penerimaan pemungutan pajak bumi dan bangunan empat tahun terakhir. Data penelitian digali melalui metode kualitatif. Penelitian ini membandingkan bagaimana implementor (Tim intensifikasi,Camat/staf, Lurah/staf, Kepala Desa/staf) dari berbagai latar belakang kewenangan yang berbeda,yaitu: penanggungjawab, pengelola administrasi, penyampai dan pemungut dalam mengimplementasikan kebijakan. Untuk mencapai tujuan tersebut peneliti menggunakan asumsi dari proses teori implementasi kebijakan yang mengasumsikan bahwa organisasi, interpretasi dan aplikasi pada beberapa level kewenangan implementor, ternyata mereka mempunyai perbedaan persepsi dalam mencapai target dan memiliki persamaan tujuan dalam mengimplementasikan kebijakan pemungutan pajak bumi dan bangunan. Hasil penelitian menyimpulkan bahwa:ketidakkeberhasilan pencapaian target penerimaan karena: Aspek interpretasi/penafsiran terdapat kesalahan menerbitkan surat pemberitahuan pajak terhutang dan data base tidak akurat. Dari kesimpulan penelitian itu, oleh peneliti dipersepsikan dengan konsep baru yang dapat ditambahkan sebagai penguatan dalam teori implementasi kebijakan. Konsep baru adalah:"pendekatan struktural berupa komitmen organisasi pelaksana sebagai salah satu faktor penting dalam mewujudkan keberhasilan implementasi kebijakan pemungutan pajak bumi dan bangunan di Wilayah Kecamatan Sintang”.
\end{abstract}

Kata kunci: Interpretasi/penafsiran, Implementasi, Kebijakan, Pajak, Bumi dan Bangunan

Dalam rangka pembiayaan pembangunan, peranan dan potensi sektor perpajakan sangat besar artinya, melalui pajak ini pemerintah akan memperoleh dana untuk membiayai pembangunan. Sehingga peranan pajak sebagai cara untuk mendapatkan dana menjadi penting. Pemerintah dalam perpajakan antara lain telah menetapkan produk kebijakan melalui undang-undang nomor: 12 Tahun 1985 dan telah ditindak lanjuti dengan perubahan undang-undang nomor: 12 Tahun 1994 tentang pajak bumi dan bangunan. Dalam undangundang ini ketentuan mengenai kewenangan penagihan pajak bumi dan bangunan masih berdasarkan kepada Keputusan Menteri Keuangan Republik Indonesia nomor: 11007/KM04/1985, tanggal 28 Desember 1985.

Menurut ketentuan Keputusan Menteri Keuangan tersebut, ditetapkan bahwa pajak bumi dan bangunan adalah pajak pusat yang kewenangan implementasi pemungutannya di serahkan kepada Pemerintah Propinsi, yaitu
Gubernur, Pemerintah Kabupaten, yaitu Bupati dan Pemerintah Kota, yaitu Walikota. Kemudian lebih lanjut dalam undang-undang nomor: 12 Tahun 1994, diatur pula bahwa yang menjadi sasaran pajak bumi dan bangunan adalah perorangan maupun badan dengan objek pajak berupa bumi dan bangunan. Implementasi kebijakan pemungutan pajak bumi dan bangunan ini bagi Pemerintah Daerah sebagai penerimaan melalui pendapatan bagi hasil pajak, dan proposi pembagian dari penerimaan pemungutan tersebut lebih besar diperuntukan bagi Pemerintah Daerah yang memungut. Penerimaan pajak yang kian penting perananannya adalah pajak bumi dan bangunan. Dalam undang-undang nomor: 32 tahun 2004 tentang Pemerintah Daerah, dinyatakan bahwa dana perimbangan bagian Daerah di peroleh dari penerimaan pajak bumi bangunan, bea perolehan hak atas tanah dan bangunan dan sumber daya alam.

Lebih lanjut dalam undang-undang nomor: 32 Tahun 2004, dijelaskan bahwa penerimaan 
Negara dari pajak bumi dan bangunan ditetapkan bahwa untuk Pemerintah Pusat dengan imbangan sebesar 10\% (sepuluh persen), untuk Pemerintah Dearah dengan imbangan sebesar $90 \%$ (sembilan puluh persen). Dengan demikian jelas bahwa pajak bumi dan bangunan merupakan pajak Pemerintah Pusat akan tetapi peruntukan dari pembagian penerimaan sebagian besar diserahkan kembali kepada pemerintah Daerah yang memungut. Pembagian untuk Pemerintah Daerah, ditetapkan sebagai berikut: untuk pemerintah Propinsi sebesar $16,2 \%$ (enam belas koma dua persen), dan untuk Pemerintah Kabupaten/Kota sebesar 64,8\% (enam puluh empat koma delapan persen) serta untuk biaya pemungutan sebesar $9 \%$ (sembilan persen). Mengingat proposi transfer Pemerintah Pusat dalam bentuk Dana Alokasi Umum (DAU) pada Anggaran Pendapatan dan Belanja Daerah (APBD) Kabupaten Sintang sangat dominan, maka upaya memperkuat anggaran itu harus dilakukan dengan menggali potensi sumber Pendapatan Asli Daerah (PAD). Potensi Pendapatan Asli Daerah yang perlu terus diusahakan adalah melalui peningkatan penerimaan pajak dan retribusi Daerah serta mencari sumber-sumber penerimaan baru sesuai dengan semangat otonomi Daerah.

Sementara Dana Alokasi Umum (DAU) dan Dana Alokasi Khusus (DAK) terhadap Anggaran Pendapatan Belanja Daerah Kabupaten Sintang adalah sebesar $82,46 \%$ (delapan puluh dua koma empat puluh enam persen). Penerimaan bagi hasil pajak dan penerimaan bukan pajak pada tahun 2009 pertumbuhan rata-rata sebesar 7,70\% (tujuh koma tujuh puluh persen) dan kontribusi terhadap Anggaran Pendapatan Belanja Daerah Kabupaten Sintang sebesar 80,57\% (delapan puluh koma lima puluh tujuh persen). Mencermati rendah kemampuan sumber-sumber penerimaan yang berasal dari Pendapatan Asli Daerah khususnya yang berasal dari penerimaan pajak Daerah dan retribusi Daerah, diperkirakan untuk beberapa tahun ke depan di Wilayah Kabupaten Sintang masih sangat tergantung pada penerimaan yang berasal dari Pemerintah Pusat berupa; Dana Alokasi Umum (DAU), dan Dana Alokasi Khusus (DAK) serta Bagi Hasil Pajak dan Bukan Pajak.
Upaya Pemerintah Kabupaten Sintang dalam rangka meningkatkan penerimaan pemungutan pajak bumi dan bangunan antara lain adalah melalui Keputusan Bupati Sintang nomor: 18 tahun 2002 tentang petunjuk pelaksanaan tatacara penyampaian surat pemberitahuan pajak terhutang dan tata cara penagihan pembayaran, penyetoran dan pelaporan pajak bumi dan bangunan di Kabupaten Sintang. Sebagaimana telah diubah melalui Peraturan Bupati Sintang nomor: 15 tahun 2009 tentang petunjuk pelaksanaan tatacara penyampaian surat pemberitahuan pajak terhutang dan tata cara penagihan pembayaran, penyetoran dan pelaporan pajak bumi dan bangunan di Kabupaten Sintang. Untuk kelancaran pelaksanaan tugas pemungutan pajak bumi dan bangunan di Kecamatan dalam Wilayah Pemerintah Kabupaten Sintang, ditetapkan penanggungjawab pelaksanaan pemungut pajak bumi dan bangunan sebagai berikut; yaitu Wilayah Kecamatan penanggungjawab pelaksana adalah Camat, Sekretaris Kecamatan dan petugas pengelola administrasi. Penugasan pemungutan itu tertuang dalam Keputusan Bupati Sintang nomor: 52 tahun 2002 tentang petunjuk tugas pengelola administrasi pajak bumi dan bangunan dan pemungutan atau penyetor pajak di Wilayah Kecamatan. Keputusan Bupati Sintang nomor: 1106 tahun 2009 tentang pembentukan Tim Intensifikasi pajak bumi dan bangunan serta penetapan besar prosentase biaya pemungutan pajak bumi dan bangunan Kabupaten Sintang Tahun Anggaran 2009 dan Keputusan Bupati Sintang nomor: 1108 tahun 2009 tentang penetapan tugas pengelola dan besar persentase insentif pajak bumi dan bangunan. Berdasarkan Keputusan Bupati Sintang nomor: 18 tahun 2002, dan nomor: 52 tahun 2002 serta Peraturan Bupati Sintang nomor: 15 tahun 2009 dapat dinyatakan sebagai harapan untuk meningkatkan aktivitas dalam implementasi kebijakan pemungutan pajak bumi dan bangunan di Kabupaten Sintang agar penerimaan berhasil sesuai dengan target yang ditetapkan.

Penerimaan pemungutan pajak bumi dan bangunan pada sektor perkotaan yang sebagian besar penerimaan belum berhasil sesuai dengan 
target, sementara capaian realisasi penerimaan pemungutan selama 4 (empat) tahun secara ratarata realisasi penerimaan hanya sebesar $56,43 \%$ (lima puluh enam koma empat puluh tiga persen) dari target. Peningkatan besarnya penetapan target setiap tahun di Wilayah Kecamatan Sintang, diperoleh informasi melalui wawancara dengan Dinas Pendapatan Pengelolaan Kekayaan dan Aset Daerah bahwa; terjadi peningkatan penetapan target karena: (1). Perubahan nilai harga dalam masyarakat, (2). Penduduk di suatu daerah berkembang, (3). Pendapatan individu bertambah, (4). Data tunggakan wajib pajak atau surat pemberitahuan pajak terhutang tahun sebelumnya, (5). Penambahan wajib pajak baru, (6). Perubahan nilai jual objek pajak, (7). Perubahan klasifikasi nilai jual objek pajak, dan (8). Perubahan penetapan nilai jual objek pajak tidak kena pajak.

Studi kebijakan publik sebagai suatu proses yang dinamis dan merupakan studi yang cukup luas, karena menyentuh wilayah studi kebijakan yang terpola dalam jalinan mata rantai dari proses kebijakan itu sendiri, oleh Lester dan Stewart (2000:27) menyatakan bahwa:"studi kebijakan publik kini telah meliputi berbagai tahap seperti terangkum dalam lingkaran kebijakan publik (public cycle).

Memperhatikan proses kebijakan tersebut, secara empirik tahapan implementasi kebijakan merupakan salah satu bagian tahapan penting dalam lingkaran kebijakan, sebab tanpa adanya implementasi kebijakan, maka suatu kebijakan yang dibuat hanya akan menjadi dokumen resmi bagi birokrasi. Implementasi kebijakan yang berhasil menjadi faktor penting dalam keseluruhan proses kebijakan. Menurut Jones (1995: 294) menyatakan bahwa: Implementasi kebijakan merupakan aspek yang penting dari keseluruhan proses kebijakan. Implementasi kebijakan merupakan tahap yang dianggap krusial dalam proses kebijakan publik". Krusial yang dimaksudkan adalah suatu suatu kebijakan harus diimplementasikan agar mempunyai dampak atau tujuan yang diinginkan. Dari pandangan Jones di atas, menjelaskan bahwa suatu kebijakan akan mempunyai suatu makna atau akan berarti apabila proses keluruhan kebijakan tersebut dapat terimplementasikan.

Kajian tentang proses menyeluruh suatu kebijakan, oleh Saefullah (2009:50) yang mengemukakan bahwa implementasi adalah: Pelaksanaan dari kebijakan yang diambil berdasarkan informasi dari hasil penelitian yang mendalam dan menyeluruh biasanya tidak akan mengalami banyak kesulitan. Kesulitan atau masalah yang timbul karena ketidakcocokan antara kebijakan yang telah diambil dengan kenyataan yang ada dilapangan. Kadang-kadang masalah tersebut menyangkut aspek-aspek yang tidak bisa diukur secara kuantitatif. Umpamanya aspek-aspek yang berhubungan dengan sistem nilai, perbedaan budaya, persepsi atau pemahaman, rasa keadilan dan keterusterangan dan lain sebagainya. Berdasarkan pandangan dari Saefullah, dapat dikatakan bahwa salah satu tolok ukur keberhasilan suatu kebijakan terletak pada proses menyeluruh aktivitas kajian kebijakan baik secara kuantitatif maupun secara kualitatif sesuai dengan karakteristik lingkungan dimana kebijakan itu akan diimplementasikan, sehingga pelaksanaan dari kebijakan berdasarkan penelitian yang mendalam tidak akan mengalami hambatan pada saat mengimplementasikan kebijakan.

Sehubungan dengan implementasi, Pressman dan Wildavsky (1973:4) mengemukakan bahwa:"implementation as to carry out, accomplish, fulfill, produce, complete". Maksudnya implementasi adalah: membawa, menyelesaikan, mengisi, menghasilkan, melengkapi. Pandangan Pressman dan Wildavsky ini menekankan pada arti atau konsep istilah yang berkenaan dengan implementasi. Organisasi untuk mengimplementasikan kebijakan pemungutan pajak bumi dan bangunan dapat dinyatakan sebagai kelompok kerja dan tim kerja, maka peneliti menggunakan pendapat Robbins. Robbins (1998:282) organisasi sebagai kelompok kerja adalah: Kelompok yang terutama berinteraksi untuk membagi informasi dan mengambil keputusan untuk membantu tiap anggota dalam bidang tanggungjawabnya”. Sedangkan tim kerja adalah 
kelompok yang upaya-upaya individunya menghasilkan suatu kinerja yang lebih besar daripada jumlah dari masukan-masukan individual. Dari pendapat Robbins ini, kelompok kerja berinteraksi dalam menerima dan berbagi informasi yang berkaitan dengan bidang tanggungjawab sehingga individu-individu dalam kelompok dapat menghasilkan kinerja yang baik dan lebih besar.

lebih lanjut tentang interpretasi atau penafsiran oleh kelompok kerja dalam implementasi kebijakan, oleh Jones (1984:165) mengemukakan bahwa: Penafsiran dilakukan agar menjadi rencana dan pengarahan yang tepat dan dapat diterima serta dilaksanakan. Seseorang mungkin pula mendapati bahwa mereka memiliki pandangan yang kurang begitu luas, dan juga bahwa persetujuan terhadap kegiatan itu sendiri merupakan sebuah tindakan yang semata-mata bersifat simbolis. Selanjutnya Jones menyatakan:"programs requiring inter governmental and public participation invite variabel interpersonal purposes. Inconsisten interpretation of program purpose are often not resolve". Maksudnya adalah program -program tersebut membutuhkan partisipasi masyarakat dan antar pemerintahan sehingga menimbulkan berbagai penafsiran tentang maksud program itu sendiri. Begitu juga penafsiran yang tidak konsisten dengan tujuan program seringkali tidak terpecahkan.

Penafsiran terhadap suatu kegiatan yang tepat merupakan awal yang berhasil, karena penafsiran sebagai usaha untuk mengerti apa dimaksud oleh pembentukan kebijakan dan untuk mengetahui betul apa dan bagaimana tujuan akhir (goal) itu diwujudkan. Setiap kebijakan melibatkan banyak orang dan membutuhkan dukungan dari berbagai pihak, baik dari pihak pembuat kebijakan, pihak pelaksana maupun pihak yang menjadi sasaran dari kebijakan tersebut. Penafsiran sebagai pedoman berupa kejelasan yang harus diterima oleh para pelaksana. Jones (1991: 321) dikemukakan bahwa: Penafsiran dapat dijadikan sebagai suatu patokan yang jelas harus segera ditetapkan yang mana melibatkan, pada batas minimum, suatu proses yang harus dipelajari oleh para pelaksana untuk kemudian mengembangkan sarana untuk menerapkannya, yang pasti hal terpenting pada masalah ini adalah perkiraan para pelaksana tersebut tentang ketersediaan sumber daya". Dari pendapat di atas, dikatakan bahwa penafsiran dapat mempengaruhi tingkat pemahaman dan kemauan dalam pelaksanaan. Implementasi kebijakan menuntut para implementor memiliki pengetahuan yang memadai atau profesional, maka interpretasi yang dilakukan harus jelas, supaya terciptanya kesamaan pemahaman atau persepsi yang dapat mempermudah mengimplementasikan suatu kebijakan.

Menurut Irianto (2009:7) bahwa: Pajak meupakan sumber penerimaan pemerintah yang paling aman sehingga pajak dapat menjadi sarana penting bagi berjalannya dmokrasi. Bila penguatan demokrasi lebih bersifat substantif, keterkaitan demokrasi dengan kebijakan bisa ditelusuri, ditemukan, dan dipahami". Dalam kebijakan perpajakan terlihat jelas bahwa adanya pembagian wewenang atau kekuasaan antara Negara dengan warganya dan antara pemerintah Pusat dengan pemerintah Daerah, untuk itu penciptaan relasi antar aktor demokrasi dalam perpajakan harus berhasil diciptakan. Pajak merupakan salah satu instrumen kebijakan dan bukan sekedar instrumen ekonomi untuk kebijakan menarik pendapatan. Menurut Guy Peters dalam Irianto (2009:9) mengungkapkan bahwa: Pajak merupakan instrumen penting bagi pemerintah untuk melaksanakan dan memenuhi fungsi-fungsi dasarnya dan mencapai tujuan-tujuan substantif dari kebijakan.

Irianto (2009:7-8) menyatakan bahwa: “ kebijakan perpajakan merupakan resultante( hasil) dan muara dari dua ranah penting dalam proses demokratisasi, yaitu hubungan Negara Masyarakat dan Pusat- Daerah". Gambar: 2.2. berikut ini:

Gambar : 1. Pajak Sebagai Muara Hubungan Negara- Rakyat dan Hubungan Pusat-Daerah 


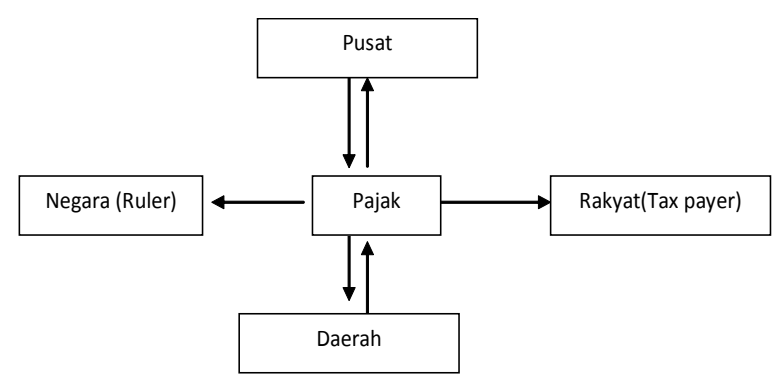

Sumber : Irianto (2009:8)

Gambar tersebut menunjukan bahwa kebijakan tentang pajak akan menentukan hubungan pajak dengan rakyat, pemerintah daerah dan pemerintah pusat dan Negara. Pajak juga sebagai jembatan penghubungan antara Negara dengan rakyat, kemudian antara pemerintah Daerah dengan pemerintah Pusat. Dalam hal ini kebijakan tentang pajak haruslah sebagai instrumen ekonomis dan menjadi penting untuk meningkatkan penerimaan Negara. Penerimaan Negara meningkat, akan semakin besar pula pembiayaan Negara serta akan semakin meningkat pelayanan kepentingan publik, oleh karenanya semakin besar pembiayaan kepentingan publik, maka akan semakin besar pula penerimaan Negara. Pembiayaan pelayanan publik melalui penerimaan dari sektor perpajakan sebagai cermin kemandarian pembiayaan Negara dapat diketahui bahwa rendahnya alokasi Anggaran Pendapatan dan Belanja untuk mendanai penyediaan barang dan jasa publik merupakan salah satu penyebab rendahnya tingkat pelayanan publik. Fungsi alokasi Anggaran Pendapatan dan Belanja adalah untuk mengakolaksikan dana guna memenuhi kebutuhan pelayanan publik yang dibutuhkan oleh masyarakat. Secara umum, sumber penerimaan yang mendukung anggaran diperoleh antara antara lain melalui penerimaan pajak serta sumber hutang luar Negeri. Permasalahan klasik dalam managemen keuangan Negara adalah adanya kebutuhan pengeluaran atau belanja yang terus meningkat, yang tidak diimbangi dengan sisi penerimaan Negara. Salah satu cara unuk meningkatkan potensi penerimaan dari sumber perpajakan adalah dengan menciptakan efektifitas sistem perpajakan. Antara lain sistem perpajakan tersebut adalah melalui pajak bumi dan bangunan.
Menurut Siahaan (2009: 52) dinyatakan bahwa: "pajak merupakan salah satu sumber penerimaan Negara yang sangat penting artinya bagi pelaksanaan dan peningkatan pembangunan Nasional". Peningkatan pembangunan Nasional yang dimaksud adalah bertujuan untuk meningkatkan kemakmuran dan kesejahteraan rakyat, dan oleh karena itu perlu dikelola dengan meningkatkan peran serta masyarakat sesuai dengan kemampuannya. Pajak bumi dan bangunan adalah bumi dan bangunan memberikan keuntungan dan atau kedudukan sosial ekonomi yang lebih baik bagi orang atau badan yang mempunyai hak atasnya atau memperoleh manfaat dari padanya, dan oleh karena itu wajar apa-bila mereka diwajibkan memberikan sebagian dari manfaat atau kenikmatan yang diperolehnya kepada Negara melalui pajak. Dasar hukum pajak bumi dan bangunan adalah undang-undang nomor : 12 tahun 1985 sebagaimana telah diubah dengan undang-undang nomor : 12 tahun 1994. Kemudian dalam undang-undang nomor: 28 tahun 2009 tentang pajak Daerah dan retribusi Daerah, dinyatakan bahwa pajak bumi dan bangunan perdesaan dan perkotaan termasuk jenis pajak kabupaten/kota".

Dalam ketentuan umum undang-undang nomor: 28 tahun 2009 dinyatakan bahwa: Pajak bumi dan bangunan perdesaan dan perkotaan adalah pajak atas bumi dan /atau bangunan yang dimiliki, dikuasai dan/atau dimanfaatkan oleh orang pribadi atau badan, kecuali kawasan yang digunakan untuk kegiatan usaha perkebunan, perhutanan dan pertambangan". Bumi adalah permukaan bumi yang meliputi tanah dan perairan pedalaman serta laut wilayah kabupaten/kota". Kemudian: "bangunan adalah konstruksi teknik yang ditanam atau dilekatkan secara tetap pada tanah dan/atau perairan pedalaman dan /atau laut". Berdasarkan penjelasan dalam undang-undang tersebut di atas, lebih lanjut tentang bangunan, oleh Mardiasmo (2008: 315) termasuk dalam pengertian " bangunan adalah : Jalan lingkungan dalam satu kesatuan dengan komplek bangunan, jalan tol, kolam renang, pagar mewah, tempat olah raga, galangan 
kapal, dermaga, taman mewah, tempat penampungan /kilang minyak, aiar dan gas, pipa minyak dan fasilitas lain yang memberikan manfaat". Dengan demikian pengertian tentang bangunan dalam pajak ini lebih luas. Kemudian asas pajak bumi dan bangunan adalah: “(1). Memberikan kemudahan dan kesedarhanaan, (2). Adanya kepastian hukum, (3). Mudah dimengerti dan adil, (4). Menghindari pajak berganda".

Berdasarkan pernyataan Mardiasmo dan penjelasan dalam undang-undang nomor: 28 tahun 2009, maka dapat disimpulkan bahwa asas pajak bumi dan bangunan menghendaki bahwa obyek pajak adalah bumi dan bangunan dan subyek pajak adalah orang pribadi atau badan harus didata secera seksama untuk mencitpakan asas kemudahan, kepastian, keadilan dan mengindari adanya pajak berganda dalam penentuan nilai jual objek pajak . Menurut undang-undang nomor: 28 tahun 2009 tentang pajak Daerah dan retribusi Daerah, dinyatakan bahwa: Nilai objek pajak adalah rata-rata yang diperoleh dari transaksi jual beli yang terjadi secara wajar, dan bilama mana tidak terdapat transaksi jual beli, nilai jual objek pajak ditentukan melalui perbandingan harga dengan objek lain yang sejenis, atau nilai perolehan baru, atau nilai jual objek pajak pengganti”.

Subyek pajak adalah orang pribadi atau badan yang dapat dikenakan pajak. Kemudian wajib pajak adalah orang pribadi atau badan, meliputi pembayar pajak, pemotong pajak dan pemungut pajak, yang mempunyai hak dan kewajiban perpajakan sesuai dengan ketentuan peraturan perundang-undang perpajakan daerah. Pemungutan adalah suatu rangkaian kegiatan mulai dari perhimpunan data objek dan subyek pajak atau retribusi, penentuan besarnya pajak atau retribusi yang terutang sampai kegiatan penagihan pajak atau retribusi kepada wajib pajak atau wajib retribusi serta pengawasan penyetorannya. Surat pemberitahuan objek pajak yang selanjutnya disingkat (SPOP), adalah surat yang digunakan oleh wajib pajak untuk melaporkan data subyek dan objek pajak bumi dan bangunan perdesaan dan perkotaan sesuai dengan ketentuan peraturan perundang-undangan perpajakan Daerah. Surat pemberitahuan pajak terhutang adalah surat yang digunakan untuk memberitahukan besarnya pajak bumi dan bangunan perdesaan dan perkotaan yang terhutang kepada wajib pajak dan surat tagihan pajak (STP). SPPT dan STP adalah dijadikan sebagai dasar penagihan pajak.

Menurut Mardiasmo (2008: 326) menyebutkan bahwa: S urat pemberitahuan objek pajak hanya diberikan dalam hal : (1). Objek pajak belum terdaftar/data belum lengkap; (2).Objek pajak telah terdaftar tetapi data belum lengkap;(3). NJOP berubah/pertumbuhan ekonomi; (4). Objek pajak dimutasikan/laporan dari instansi yang berkaitan langsung dengan objek pajak". Dengan demikian SPOP akan dikenal dengan SPOP kembali, SPOP tidak kembali, SPOP kembali tetapi tidak benar, dan SPOP dintinjau dari Sifat dan fungsinya. Dalam peraturan bupati sintang nomor : 2 tahun 2007 sebagaimana telah dirubah dengan peraturan bupati sintang nomor : 15 tahun 2009 tentang petunjuk pelaksanaan tata cara penyampaian surat pemberitahuan pajak terhutang (SPPT), penagihan/ pembayaran serta pelaporan pajak bumi dan banguan di kabupaten sintang, bahwa tata cara penyampaian surat pemberitahuan pajak terhutang pajak bumi dan bangunan adalah sebagai berikut :Surat pe mberitahuan pajak terhutang PBB ( SPPT-PBB) diserahkan oleh Dinas Pendapatan Pengelola Keuangan dan Aset Kabupaten Sintang kepada Camat dengan dilengkapi Berita Acara (BA) penyerahan selanjutnya Camat menyerahkan ke Lurah/Kepala Desa dengan dilengkapi Berita Acara (BA) . Berita acara penyerahan ditanda tangani oleh ; a) unsur Dinas Pendapatan Pengelola Keuangan dan Aset Kabupaten Sintang sebagai pihak yang menyerahkan, b) Camat dan Lurah/ Kepala desa sebagai penerima. Berita Acara dibuat dalam 5 (lima) rangkap yang dibagikan kepada : a) lembara 1 untuk Dinas Pendapatan Pengelolaan Keuangan dan asset Kabupaten Sintang, b) lembar 2 untuk Camat, c) lembar 3 untuk Kelurahan/Desa, d) lembar 4 untuk KPP, Pratama Sintang, e)lembar 5 untuk ketua Tim intensifikasi pajak bumi dan bangunan Kabupaten Sintang. Penyampaian SPPT 
-PBB kepada wajib pajak sepenuhnya menjadi tanggungjawab lurah/kepala desa. Penyampaian SPPT-PBB, dalam pelaksanaannya Lura/Kepala Desa dapat menunjuk aparat Kelurahan/Desa atau Kepala Dusun dan petugas lainnya melalui Surat Penunjukan dari Lurah/Kepala Desa. SPPT-PBB yang diserahkan Lurah/Kepala Desa kepada petugas penyampaian SPPT-PBB harus diadministrasikan dengan menggunakan Daftar Tanda Terima Penyerahan, sebagaimana terlampir pada lampiran II pada peraturan ini. Penyampaian SPPT-PBB kepada wajib pajak dilaksanakan selambat-lambatnya 20 (dua puluh) hari sejak tanggal diterima SPPT-PBB dari DPPKA Kabupaten Sintang. Penyampaian SPPT-PBB dapat disampaikan dengan cara: a) SPPT-PBB dapat diambil sendiri oleh wajib pajak sendiri atau kuasanya di Kantor Lurah/Kepala Desa atau Tempat Lain yang telah ditunjuk khusus, setelah diumumkan oleh Lurah/Kepala Desa dengan cara yang dianggap efektif, b) SPPT-PBB dapat disampaikan langsung oleh petugas kepada wajib pajak atau kuasanya. Penyampaian SPPT-PBB dilaksanakan secara serentak dalam satu wilayah Kecamatan, Kelurahan/Desa. STTS dan daftar himpunan ketetapan pajak (DHKP) PBB diserahkan oleh Kantor Pelayanan PBB ( KPP Pratama) Sintang kepada Bank Persepsi yaitu. PT Bank Kalbar Cabang Sintang dan selanjutnya didistribusikan kepada Bank Kalbar Cabang pembantu. Apabila Bank Persepsi belum memiliki kantor unit disetiap Kecamatan sedangkan wilayah Kabupaten Sintang yang cukup luas, serta jarak tempuh dari Ibukota Kecamatan ke Desa relative jauh, maka untuk penetapan STTS di koordinasikan oleh Camat dengan PT Bank Kalbar Cabang Sintang dan hasil kesepakatan antara kedua belah pihak dituangkan dalam berita acara. Kemudian penagihan dan pembayaran pajak bumi dan bangunan adalah: Penagihan atau pemungutan PBB dapat dilakukan oleh petugas pemungut yang ditunjuk oleh Lurah/Kepala Desa dengan keputusan Lurah/Kepala desa.Wajib pajak dapat membayar PBB secara langsung kepada Bank Persepsi yaitu Bank Kalbar dengan menunjuk SPPT-PBB.
Konfimasi (pencocokan) disebutkan bahwa konfirmasi (pencocokan) surat tanda terima setoran dapat dilakukan sebelum maupun sesudah jatuh tempo. Pencocokan tanda terima ini sebelum jatuh tempo dapat dilakukan 3 (tiga) bulan atau 15 (lima belas) hari menjelang jatuh tempo. Hal ini dimaksudkan untuk menerbitkan Surat Himbauan kepada lurah/kepala desa. Pelaksanaan pencocokan surat tanda terima setoran dilakukan oleh 3 (tiga) pihak yaitu : a). KPP.pratama sintang, b). DPPKA kabupaten sintang dan c). Petugas tempat pembayaran. Keberatan dan pengurangan pajak bumi dan bangunan sebagaimana diatur pada peraturan bupati sintang nomor: 15 tahun 2009, yaitu keberatan dapat diajukan oleh wajib pajak (WP) dikarenakan pajak terutang pada surat pemberitahuan pajak terhutang bumi dan bangunannya tidak sesuai dengan keadaan sebenarnya. Hal ini terjadi karena adanya beberapa kesalahan seperti: a). Kesalahan pada luas objek pajak, b). Kesalahan klasifikasi objek, baik untuk kelas jalan atau kelas bangunan yang dirasakan terlalu tinggi, c). Kesalahan pada penetapan / pengenaan pajak terhutang.

Penerapan sanksi, yaitu bagi wajib pajak pada surat pemberitahuan pajak terhutang telah dicantumkan tanggal jatuh tempo pembayaran, apabila wajib pajak melakukan pembayaran setelah lewat tanggal jatuh tempo akan dikenakan denda/ sanksi administrasi sebesar $2 \%$ (dua persen) setiap bulan untukjangka waktu paling lama 24 (dua puluh empat) bulan. Bagi wajib pajak jumlah pajak terhutang berdasarkan surat tanda pajak yang tidak dibayar, dapat ditagih dengan surat paksa. Jika pajak bumi dan bangunan tidak dibayar wajib pajak, maka akan dilakukan penyitaan terhadap objek pajak sesuai dengan jumlah pajak terhutang yang bersangkutan.

Berdasarkan Peraturan Direktur Jenderal Pajak nomor : 6/PJ/2008 tentang tata cara pengurangan denda administrasi pajak bumi dan bangunan, atas permintaan wajib pajak dapat mengurangi denda administrasi karena hal-hal tertentu, yaitu denda yang meliputi : a). Denda administrasi sebesar $25 \%$ (dua puluh lima persen) 
dihitung dari pokok pajak yang tercantum dalam surat keterangan pajak bumi dan bangunan, b). Denda administrasi sebesar $2 \%$ (dua persen). Implementasi kebijakan pemungutan pajak bumi dan bangunan adalah berkenaan sebagai usaha untuk menjawab sebagaimana yang tertuang dalam undang-undang nomor:12 tahun 1994, diimplementasikan kebijakan pemungutan pajak ini, tidak terlepas dari berbagai kepentingan yang berhubungan dengan dana, material dan orang yang terlibat dalam rangka meningkatkan penerimaan pemungutan pajak bumi dan bangunan ini. Implementasi kebijakan pemungutan pajak bumi dan bangunan yang berhubungan dengan dana yang dimaksudkan adalah menyangkut penerimaan keuangan negara melalui pajak. Material yang dimaksudkan adalah berbagai sarana dan prasrana penunjang dalam pemungutan maupun material sebagai obyek pajak. Sementera itu orang yang dimaksudkan adalah orang sebagai pegawai pelaksana pemungut dan orang sebagai subyek atau sasaran wajib pajak.

Andiwinata (Koordinasi Regional Pajak Bumi dan Bangunan, 1995-5-8) menyatakan bahwa: "peningkatan penerimaan pajak bumi dan bangunan perlu menggali potensi melalui intensifikasi dan ekstensifikasi pendataan obyek dan subyek pajak". Pendataan itu perlu dengan pola system managemen informasi obyek pajak (sismiop) system dan prosedur pemungutan dan pembayaran yang sistematis, mudah dan aman serta pelayanan yang lebih baik. Berkaitan dengan pajak, banyak para ahli dalam bidang perpajakan memberikan pengertian yang berbeda mengenai pajak, namun demikian berbagai pengertian tersebut mempunyai inti atau tujuan yang sama. Sehubungan dengan definisi pajak, menurut Djadinigrat, sebagaimana dikutip dalam Munawir (1992: 140) menyatakan bahwa: Tujuan dari pemungutan pajak untuk biaya pemeliharaan kesejahteraan umum juga memberikan sebab-sebab pengenaan pajak, karena keadaan, kejadian dan perbuatan yang memberikan kedudukan tertentu, tetapi bukan hukuman.

Pengenaan pajak oleh Adam Smith dalam Suparmoko (1994:97-98) yaitu: “mempunyai prinsip, yaitu prinsip kesamaan/keadilan, prinsip kepastian, prinsip kecocokan/kelayakan dan prinsip ekonomi". Untuk itu pajak hendaknya menimbulkan kerugian yang menimal dalam arti jangan sampai biaya pemungutannya lebih besar dari pada jumlah penerimaan pajaknya. Dari sudut pemerintah di kehendaki, agar pajak menunjukan elastisitasnya, yakni kemampuan untuk menghasilkan tambahan pendapatan agar dapat menutup tuntutan yang sama atas kenaikan pengeluaran pemerintah, dan dasar pengenaan pajaknya berkembang secara otomatis, misalnya; apabila harga-harga meningkat, penduduk di suatu daerah berkembang dan pendapatan bertambah. Menurut Davey (1988: 41) yaitu: "elastisitas pajak dapat diukur dengan membandingkan hasil penerimaan selama beberapa tahun dengan perubahan -perubahan dalam indeks harga, penduduk dan pendapatan". Gambaran mengenai elastisitas pajak lebih dari sekedar data penerimaan pajak, karena elastisitas pajak dapat mencerminkan pertumbuhan yang otomatis dalam potensi pajak, terlepas dari keputusan untuk mengubah tarif pajak. Suatu kebijakan akan mudah diimplementasikan, apabila manfaatnya segera dirasakan oleh masyarakat sebagai kelompok sasaran dari kebijaksanaan itu. Program-program pemerintah seperti listrik masuk Desa, irigasi pertanian, dan perbaikan jalan, mempunyai manfaat yang jelas dan dapat segera dinikmati masyarakat, sehingga mudah memperoleh dukungan dari mereka.

Lain halnya dengan kebijakan pemungutan pajak bumi dan bangunan . manfaat program ini, meskipun mudah dijelaskan, tetapi tidak secara langsung dan segera dapat dinikmati oleh kelompok masyarakat. Bahkan program pemungutan pajak bumi dan bangunan dapat dianggap sebagai beban atas kepemilikan bumi dan bangun bagi segelintir masyarakat. Akan tetapi bagi masyarakat secara umum mengganggap bahwa program pemungutan pajak bumi dan bangunan merupakan waujud kewenangan pemerintah dan mereka wajib mematuhi, tanpa memahami prinsip dan kreteria program yang berlaku atau dijalankan. Kreteria kebijakan yang berkaitan dengan pajak bumi dan 
bangunan yang terpenting adalah yang menyangkut pajak dengan system progresif, yakni kaya membantu yang miskin. Mardiasmo (2008: 4) menyatakan: Dasar keadilan terletak pada akibat pemungutan pajak, yaitu memungut pajak berarti menarik daya beli dari rumah tangga masyarakat untuk rumah tangga Negara. Selanjutnya Negara akan menyalurkannya kembali ke masyarakat dalam bentuk pemeliharaan kesejahteraan masyarakat. Dengan demikian kepentingan seluruh masyarakat lebih diutamakan.

Pendapat Mardiasmo menjelaskan bahwa pajak dilakukan untuk menciptakan rasa keadilan bagi masyarakat, dengan tidak mengurangi kemampuan masyarakat dalam memenuhi kebutuhan hidupnya, dan dampak penarikan atau pemungutan penetapan pajak yang diberlakukan kepada masyarakat, oleh pemerintah pemungutan tersebut sebagai penerimaan untuk pembiayaan pembangunan yang mampu meningkatkan kesejahteraaan masyarakat. Sumitro (1989:86) dinyatakan bahwa: Pajak bumi dan bangunan akan meliputi orang atau badan yang menguasai tanah atau bangunan bahkan orang atau badan yang memperoleh manfaat dari tanah atau bangunan, tanpa memiliki atau mempunyai hak yang atas tanah atau bangunan". Dasar pengenaan pajak bumi dan bangunan adalah nilai jual obyek pajak, yaitu harga rata-rata yang diperoleh dari transaksi jual beli yang terjadi secara wajar dan bilamana tidak terdapat transaksi jual beli, maka penentuan nilai jual obyek pajak diperoleh melalui perbandingan harga dengan obyek lain yang sejenis, atau melalui nilai perolehan baru, atau dengan nilai jual obyek pajak pengganti. Pengenaan pajak bumi dan bangunan ini, menurut Devas (1989: 128) dinyatakan bahwa: Ada empat manfaat dari penggunaan nilai jual menurut harga pasar sebagai dasar pajak. Pertama: perkembangan nilai tanah itu diperhitungkan. Kedua: tidak perlu lagi ada pajak terpisah untuk tanah kosong. Ketiga: nilai jual tanah akan memungkinkan dasar pajak naik seiring dengan kenaikan nilai tanah akibat dikembangkan dan Keempat: data mengenai nilai sewa, jika ada dapat selalu digunakan untuk memeriksa nilai kena pajak berdasarkan nilai jual”.

Dalam prakteknya penetapan besarnya pajak juga mempertimbangkan letak tanah termasuk kelasnya. Apabila terletak ditepi jalan besar, maka tarifnya akan lebih mahal jika dibandingkan dengan tanah yang terletak ditengah-tengah kampong. Letak tanah di kota lain dengan di desa. Bahkan antara desa yang satu dengan yang lain, semakin jauh dari kota, maka semakin murah nilai jual tanah.

Persoalan teknis yang muncul, misalnya pengukuran tanah. Begitu pula halnya apabila seseorang memiliki tanah pekarangan, kemudian sebagian tanahnya disumbangkan untuk jalan kampong. akan tetapi pemilik tanah masih dikenakan PBB untu tanah yang disumbangkan itu, tentu saja yang bersangkutan keberatan, karena telah menyumbang, tetapi masih dibebani pajak bumi dan bangunan. Pelaksanaan pajak tetap memberikan kesempatan kepada rakyat dalam meningkatkan hidupnya lebih baik, serta pajak harus menjamin kebebasan individu dalam arti bahwa pajak di jalankan jangan memberatkan beban rakyat. Pajak terlalu berat sama memberatkan beban rakyat, sehingga mengganggu dan mengurangi kebebasan individu. Salah satu lingkungan yang sangat besar pengaruhnya terhadap implementasi pungutan pajak bumi dan bangunan adalah sikap dari kelompok sasaran (wajib pajak), suatu pertanyaan penting dalam proses pelaksanaan pemungutan $\mathrm{PBB}$ adalah apakah ada pihak tertentu sebagai wajib pajak yang dirugikan dari adanya pungutan PBB yang tidak sesuai dengan ketentuan yang berlaku. Implementasi kebijakan pemungutan pajak bumi dan bangunan yang berkaiatan dengan sikap, yang secara bebas sikap dapat diterjemahkan sebagai suatu cara bereaksi terhadap suatu rancangan yang timbul dari seseorang atau dari suatu situasi yang dapat melahirkan sikap keterusterangan bertindak atau tidak bertindak. Penjelasan mengenai sikap seseorang maka peneliti mengemukakan pendapat Indrawijaya.

Indrawijaya (1986:43-44) menyatakan bahwa: Sikap seseorang dapat mengalami perubahan, baik karena proses interaksi dengan lingkungan maupun melalui proses pendidikan. 
Pemungutan pajak bumi dan bangunan ini, perubahan sikap dapat saja terjadi sebangun atau tidak sebangun. Perubahan sebangun adalah perubahan dalam intensitas saja. Contoh; awalnya sikap sangat setuju menjadi setuju, perubahan tidak sebangun adalah perubahan yang bersifat sangat setuju dan kebalikannya. Pandangan wajib pajak terhadap beban PBB yang ditanggung, dapat diketahui melalui pemahaman wajib pajak terhadap perhitungan beban obyek pajak yang mereka tanggung. Sehingga pemahaman ini dapat mengetahui berat-tidaknya beban pajak bumi dan bangunan yang ditanggung oleh wajib pajak yang bersangkutan. Berkenaan dengan beban biaya pajak bumi dan bangunan, persoalan yang mungkin muncul dan harus diperhatikan adalah bahwa pelaksanaan penetapan perhitungan obyek PBB dilaksanakan secara sunggug-sungguh, sehingga masyarakat sebagai wajib pajak dapat menerima penetapan tersebut sebagai sesuatu yang adil dan merata. Besar kecilnya beban biaya pajak bumi dan bangunan bukan sesuatu yang menjadi prioritas pelaksanaan pungutan bagi penerimaan pajak, melainkan aturan dan mekanisme penetapan nilai jual obyek pajak dan nilai jual obyek pajak tidak kena pajak yang harus diterapkan sesuai dengan realitas obyek pajak yang sesungguhnya. Dalam pemungutan pajak bumi dan prsoalan kepatuhan wajib pajak membayar pajak bumi dan bangunan merupakan tolak ukur untuk keberhasilan implementasi kebijakan tentang anggaran yang ditetapkan pemerintah melalui pelaksanaan pungutan penerimaan pajak bumi dan bangunan. Dimana kepatuhan membayar pajak bumi dan bangunan, akan menentukan upaya pajak yang ditetapkan, menentukan hasil guna pajak dan bahkan menentukan dayaguna pajak yang diharapkan. Kepatuhan yang dimaksud untuk mengetahui kemampuan wajib pajak dalam membayar pajak, sehingga diperoleh penerimaan pajak bumi dan bangunan secara maksimal.

Implementasi kebijakan pemungutan pajak bumi dan bangunan yang didukung oleh kepatuhan wajib pajak membayar pajak dapat menentukan hasilguna pajak serta untuk mengukur hasil pungutan suatu pajak dan potensi pajak dengan membayar seluruh pajak terhutang. Kepatuhan wajib pajak membayar pajak dengan maksud bahwa bagian hasil pajak yang dipungut lebih besar dan digunakan secara maksimal serta dapat menutup atau menekan biaya pungut serendah mungkin. Jones (1984: 177) menjelaskan tentang interpretasi atau penafsiran dalam implementasi kebijakan dengan mengajukan pertanyaan pokok bagi si pelaksana adalah: " apa yang harus saya lakukan sekarang? Sebuah kebijakan telah disetujui dan organisasi sudah siap". Pendapat yang senada, oleh George C. Edwards dalam Jones (1984:178) menyatakan bahwa: Syarat pertama bagi implementasi kebijakan yang efektif adalah bahwa orang-orang yang akan mengimplementasikan suatu keputusan harus mengetahui apa yang seharusnya mereka lakukan. Bilamana kebijakankebijakan hendak diimplementasikan dengan tepat, petunjuk untuk mengimplementasikannya tidak hanya untuk diterima tetapi juga harus jelas. Bila tidak maka pelaksananya akan kebingungan akan apa yang seharusnya dilakukan, dan juga aka ada keleluasaan untuk menerapkan pandangannya sendiri pada implementasi kebijakan, suatu pandangan yang bisa saja berbeda dari pandangan para atasannya.

Implementasi kebijakan yang efektif kecil kemungkinannya terjadi bila kejelasan belum cukup. Telah menjadi hukum tidak tertulis bahwa semakin kompleks sebuah isu sosial, maka semakin ambigu kebijakan sosial. Dan sebagaimana dikatakan Edward, ambiguitas akan menimbulkan keleluasaan bagi pelaksananya, meskipun keleluasan itu tidak untuk memperluas otoritasnya. Sebaliknya, keleluasaan tersebut dipakai untuk menghindari isu-isu sulit. Standar yang jelas harus diterapkan, yang meliputi setidaknya sebuah proses dimana pelaksana kebijakan bisa mengetahui apa yang menjadi standar dan mengembangkan cara menerapkannya. Apakah pelaksananya mau melakukan tanggung jawab tersebut dan bagaimana ia melakukannya tergantung pada beraneka macam kondisi. Yang pasti, kondisi yang paling penting di antara kondisi-kondisi tersebut adalah 
estimasi yang dimiliki oleh pelaksana kebijakan mengenai sumber daya yang tersedia. Undangundang sendiri belum berubah banyak, namun interpretasi atas undang-undang tersebut dari segi penerapan praktisnya telah banyak mengalami perubahan.

Bahwa pelaksana kebijakan harus merespon pertanyaan, apa yang seharusnya saya lakukan sekarang?. Sudah pasti akan menyebabkan frustasi bagi mereka yang menyukai kerapian dalam klosur proses kebijakan. Karena itu, tidaklah mengherankan bahwa formula administrasi yang baik atau implementasi yang efektif harus dikembangkan. Formula-formula yang demikian biasanya menekankan kejelasan, presisi, konsistensi, penetapan prioritas, sumberdaya yang cukup, dan sejenisnya. Kajian administrasi publik penuh dengan petunjuk-petunjuk semacam itu untuk manajeman yang baik. Analisis yang lebih kontemporer tentang implementasi menurut beberapa ahli antara lain menurut Bardach, Edwards, Hargrove, Hofferbert, Mazmanian dan Sabatier, Pressman dan Wildavsky, Ripley dan Franklin, Van Horn dan Van Meter, mereka menjelaskan perbedaan-perbedaan yang terkadang dramatis dalam prilaku implementasi kebijakan dilihat dari tingkat keragaman kondisi sosial, politik, legal, dan organisasional.

Mazmanian dan Sabatier dalam Jones (1984:179) memberikan seperangkat variabel yang paling terperinci. Variabel yang berkaitan dengan kemampuan menelusuri permasalahan, Variabel yang berkaitan dengan sejauhmana ketentuan undang-undang menstrukturisasi implementasi: Variabel diluar ketentuan undang-undang yang dapat memberi dampak pada implementasi. Daftar ini menjadi inventarisasi atas faktor-faktor yang dapat menjelaskan perbedaan tingkat keberhasilan yang dibuat oleh para pelaksana dalam menjalankan program. Mazman dan Sabatier menggunakan faktor-faktor ini untuk mengkaji beberapa wilayah kebijakan, dan tentu saja mereka menemukan perbedaan hasil yang sangat mencolok. Bisa jadi ada cara yang paling baik dalam pengimplementasian, namun tidak ada metode yang bisa diberlakukan sama dalam implementasi.

Proses kebijakan sangat tergantung pada cara berkomunikasi dan pemaknaan. Interpretasi:"Apa maksud sesungguhnya?", adalah penting dalam memahami apa yang terjadi pada setiap tingkatan pembuatan keputusan. Hal ini diberi penekanan karena sering kali kita beranggapan bahwa hukum, keputusan-keputusan, petunjuk-petunjuk, dan perintah-perintah bersifat definitif. Sering kali juga harus memperhatikan cara para pelaksana menginterpretasikan tanggung jawabnya dalam mengimplementasikan kebijakan. Analisis ini harus mencakup pemahaman atas sebab-sebab adanya interpretasi semacam itu. Lalu kepada siapa pelaksananya bertanya? Siapa yang dianggap berkuasa? Kedua pertanyaan ini akan mengeksplorasi seberapa banyak keleluasan yang para penyelenggara pikir mereka miliki.

Jawaban atas pertanyaan tersebut juga mungkin akan membantu menjelaskan keterlambatan yang dilukiskan oleh Bardach dalam Jones (1984:179) sebagai "suatu atribut dalam proses implementasi dimana semua orang akan setuju kalau hal ini merupakan gejala dari sebuah patologi (penyakit) dan Bardach mengatakan: Implementasi membutuhkan waktu panjang, lebih lama dari harapan para sponsor akan waktu yang diperlukan oleh kebanyakan program. Bilamana pada akhirnya keluaran-keluaran tertentu ingin didapat, mengapa tidak didapat lebih awal? Tanyakan saja kepada perancang kebijakan dan para pendukungnya. Jawabannya lebih banyak terletak dalam resiko-resiko, kerumitan, dan ketidakpastian dalam upaya mencoba melakukan sesuatu.

Alasan lain pentingnya mendalami apa, bagaimana, dan siapa yang menginterpretasikan adalah bahwa kajian semacam itu akan selalu memusatkan perhatian pada harapan para penyelenggara dan orang lain atas program. Pencarian semacam ini akan membawa seseorang kepada inti yang paling dalam dari subtansi kebijakan, kepada pertanyaan tentang apa yang dipikirkan akan terjadi oleh pembuat kebijakan 
bilamana sebuah program disetujui dan diimplementasikan. Tentu saja kita akan tau bahwa tidak banyak yang ada dalam benak mereka, bahwa menyetujui program tidak lebih dari sebuah tindakan yang bersifat simbolis. Interpretasi atau penafsiran dalam implementasi kebijakan, oleh Jones (1984:180) menyatakan bahwa:"kajian tentang interpretasi pada saat pengimplementasian kebijakan akan mendapatkan mata rantai-mata rantai yang lainnya”.

Tanggungjawab dalam implementasi kebijakan sepenuhnya diletakan pada kewajiban tugas aparat pemerintah sebagai implementor, mereka dituntut memiliki interpretasi yang tepat dalam menjalankan tugas terimplementasinya kebijakan. Interpretasi yang tepat menurut penulis memerlukan dukungan aktivitas komunikasi yang yang baik. Agar interpretasi atau penafsiran dalam implementasi kebijakan berjalan dengan baik, maka peneliti menggunakan pendapat Robbins tentang fungsi komunikasi. Robbins (1996:5) menyatakan bahwa: "komunikasi menjalankan empat fungsi utama di dalam suatu kelompok atau organisasi, yakni: fungsi kendali (kontrol/pengawasan), motivasi, pengungkapan emosional, dan informasi”. Pandangan Robbins menghendaki bahwa: komunikasi formal dan informal bertindak sebagai pengendali perilaku anggota dengan melalui hubungan hirarkhi wewenang dan garis panduan formal yang harus dipatuhi. Komunikasi membantu perkembangan motivasi dengan menjelaskan kepada para bawahan apa yang harus dilakukan, bagaimana mereka bekerja baik, dan apa yang dapat dikerjakan untuk memperbaiki kinerja jika itu dibawah standar. Komunikasi menyiarkan ungkapan emosional dari perasaan dan pemenuhan kebutuhan sosial sebagai interaksi sosial kelompok kerja dalam organisasi. Komunikasi berhubungan dengan perannya dalam mempermudah pengambilan keputusan, dengan demikian komunikasi memberikan inforrmasi yang diperlukan individu dan kelompok untuk mengambil keputusan dengan meneruskan data guna mengenali dan menilai pilihan-pilihan alternatip. Berdasarkan pandangan itu, faktor komunikasi sebagai salah satu berperanan penting yang perlu diperhatikan terhadap interpretasi dalam implementasi kebijakan. Proses komunikasi merupakan langkah-langkah antara satu sumber dan penerima yang menghasilkan pentransferan dan pemahaman makna, sehingga proses komunikasi berperan mengubah suatu pesan komunikasi menjadi bentuk simbolik yang konkrit.

\section{METODE PENELITIAN}

Berdasarkan latar belakang masalah dan tujuan penelitian ini, maka menurut peneliti yang sesuai dengan pendekatan yang digunakan dalam penelitian ini adalah menggunakan desain penelitian kualitatif dengan metode analisis deskriptif kualitatif. Metode penelitian kualitatif dilakukan pada kondisi yang alamiah (Nutural setting). Pendekatan kualitatif digunakan oleh peneliti dengan maksud agar peneliti dapat memahami aktivitas perilaku petugas pemungut pajak bumi dan bangunan secara personal dan memandang mereka sebagaimana mereka sendiri dalam mengungkapkan pandangan aktivitasnya. Penelitian kualitatif bersifat penyelidikan dan peneliti harus mendengarkan informasi dari informan dan membuat gambaran berdasarkan keterangan mereka. Dalam tradisi penelitian kualitatif memerlukan studi lapangan (Fieldwork) yang pada hakekatnya sebagai prosedur penelitian yang menghasilkan data deskriptif berupa kata-kata atau kesan dari orang atau pelaku yang diamati, sehingga peran peneliti dijadikan instrumen utama.

Penggunaan istilah kualitatif menunjukan proses dan makna yang tidak diuji atau diukur secara akurat dari segi kuantitas, melainkan menekankan pada kondisi dari realitas dan mencari jawaban untuk diberi nama. Dengan latar belakangan demikian, maka menurut peneliti kajian studi lapangan adalah untuk memahami secara mendalam tentang pengumpulan informasi yang digunakan melalui wawancara dan observasi, yang kemudian informasi dapat dideskripsikan sesuai dengan subyek kajian yang menjadi sasaran penelitian. Sumber data dalam penelitian meliputi sumber data primer dan sekunder. Data primer 
adalah data yang diperoleh langsung dari para informan dengan cara pengumpulan langsung kelapangan dengan melakukan observasi dan wawancara kepada petugas yang terlibat dengan implementasi kebijakan pemungutan pajak bumi dan bangunan, yaitu Tim Intensifikasi pajak bumi dan bangunan Kabupaten Sintang, Kecamatan Sintang, Kelurahan dan Desa.

Data sekunder adalah data yang diperoleh dari data dokumen laporan akhir kinerja instansi pemerintah tahunan yang berhubungan dengan laporan target dan realisasi penerimaan pemungutan pajak bumi dan bangunan yang tersedia pada Kantor yang terlibat dalam implementasi kebijakan pemungutan pajak bumi dan bangunan, seperti Dinas Pendapatan Pengelolaan Kekayaan dan Aset Daerah (DPPKA), Kantor Pelayanan Pratama, Kantor Kecamatan Sintang dan Kantor Kelurahan/Desa. Data yang digunakan adalah dokumen data pajak bumi dan bangunan yang dimulai dari tahun 2006 sampai dengan tahun 2009 serta data dari berbagai hal yang berkaitan dengan daerah penelitian antara lain adalah geografis, demografis, sosial - ekonomi, budaya dan lain lain yang dianggap berguna untuk menjawab pertanyaan dalam penelitian.

Penentuan informan dalam penelitian ini ditentukan atas pertimbangan yang dilakukan peneliti ataupun oleh pihak yang memiliki kewenangan dalam memberikan jawaban terbaik tentang pertanyaan penelitian. Informan dalam penelitian ini adalah yang memiliki ciri sebagai berikut: 1). Mempunyai kewenangan dengan proses pemungutan pajak bumi dan bangunan periode tahun 2006 sampai dengan tahun 2009. 2). Mempunyai pengalaman kerja pemungutan pajak bumi dan bangunan menimal selama dua tahun. Berdasarkan ciri-ciri tersebut, maka informan penelitian adalah: a). Tim Intensifikasi pemunggutan pajak bumi dan bangunan Kabupaten. b). Camat Sintang. c). Pengelola administrasi pemungutan pajak bumi dan bangunan Kecamatan. d). Lurah e). Kepala Desa f). Staf petugas pengelola administrasi pemungut pajak bumi dan bangunan di Kelurahan/Desa.
Berdasarkan ciri informan sebagaimana yang telah dijelaskan di atas. Penjelasan yang rinci tentang informan dan argumentasi mengapa mereka dipilih, dapat dijelaskan dalam uraian berikut:

(1). Informan penting adalah adalah Bupati Sintang. Ia dipilih sebagai informan karena Bupati adalah orang yang bertanggungjawab dalam Tim Intensifikasi pajak bumi dan bangunan Kabupaten, sekaligus tahu dengan persis tentang implementasi kebijakan pemungutan pajak bumi dan bangunan.

(2). Asisten Bidang Pemerintahan Sekretariat Daerah Kabupaten sintang. Ia adalah orang yang juga sangat memahami tentang berbagai hal yang terkait dengan implementasi kebijakan pemungutan pajak bumi dan bangunan, karena Asisten Bidang Pemerintahan sebagai anggota Tim Intensifikasi pajak bumi dan bangunan Kabupaten.

(3).Kepala Bidang Pendapatan Dinas Pendapatan Pengelolaan Kekayaan dan Aset Daerah Kabupaten Sintang. Ia menjadi informan karena yang bersangkutan juga sangat memahami tentang implementasi kebijakan pemungutan pajak bumi dan bangunan dan ia adalah orang yang menyiapkan pendataan wajib pajak bumi dan bangunan sekaligus sebagai anggota Tim Intensifikasi pajak bumi dan bangunan Kabupaten.

(4). Kepala Seksi Ekstensifikasi dan Perpajakan Kantor Pelayanan Pajakk Pratama Kabupaten Sintang juga sangat memahami implementasi kebijakan pemungutan pajak bumi dan bangunan karena ia adalah sebagai anggota Tim Intensifikasi pajak bumi dan bangunan Kabupaten.

(5). Camat Sintang. Ia menjadi informan karena yang bersangkutan sebagai penanggunjawab pengelola pajak bumi dan bangunan Tingkat Kecamatan dan ia adalah orang yang sangat memahami implementasi pemungutan pajak bumi dan bangunan.

(6). Kasi Perlengkapan Kantor Kecamatan Sintang. Ia menjadi informan karena yang 
bersangkutan memahami tentang implementasi kebijakan pemungutan pajak bumi dan bangunan dan ia adalah orang yang bertugas sebagai pengelola administrasi pemungutan pajak bumi dan bangunan Kecamatan.

(7). Lurah dan Kepala Desa di wilayah Kecamatan Sintang. Mereka menjadi informan karena memahami tentang implementasi kebijakan pemungutan pajak bumi dan bangunan dan mereka sebagai penanggungjawab pengelola pemungutan pajak bumi dan bangunan wilayah Kelurahan/Desa.

(8). Kepala Seksi Ekonomi dan Pembangunan dan Kepala Seksi Pemerintahan Kelurahan di wilayah Kecamatan Sintang. Ia menjadi informan karena yang bersangkutan memahami tentang implementasi kebijakan pemungutan pajak bumi dan bangunan dan ia adalah orang yang bertugas sebagai pengelola administrasi dan pemungut pajak bumi dan bangunan kelurahan.

(9). Sekretaris Desa di wilayah Kecamatan Sintang dipilih menjadi informan karena ia juga sangat mengetahui dan menguasai implementasi kebijakan pemungutan pajak bumi dan bangunan dan yang bersangkutan bertugas sebagai pengelola administrasi dan sebagai pemungut pajak bumi dan bangunan di wilayah desa.

(10). Staf Kelurahan dan staf Desa di wilayah Kecamatan Sintang sebanyak tiga orang dipilih menjadi informan karena mereka juga sangat memahami implementasi kebijakan pemungutan pajak bumi dan bangunan dan kewenangan mereka sebagai pengelola administrasi pemungut pajak bumi dan bangunan di Kelurahan dan Desa.

Informan pangkal adalah Bupati selaku PenanggungjawabTim Intensifikasi pemungutan pajak bumi dan bangunan Kabupaten Sintang. Informasi awal dimulai dari informan pangkal, data dan informasi yang tidak diberikan oleh informan awal, yang selanjutnya menemui para informan lain dan seterusnya sehinga kepada pelaksana pemungut dilapangan dan informan sebagai wajib pajak bumi dan bangunan, sampai data dan informasi yang diperlukan mencukupi. Prosedur pengumpulan data adalah dengan melakukan langkah pengumpulan data dan teknik pengumpulan data. Langkah-langkah pengumpulan data oleh peneliti dengan melakukan: a). Menetapkan batasbatas penelitian sesuai dengan tujuan penelitian, b). Mengumpulkan informasi melalui pengamatan/ observasi, wawancara, dan dokumen, c). Menetapkan aturan untuk mencatat berbagai informasi yang berkaitan dengan penelitian ini. Langkah-langkah pengumpulan data ini dilakukan pada kondisi yang alamiah tentang sumber data primer. Kemudian teknik pengumpulan data lebih banyak pada pengamatan/observasi, wawancara mendalam dan studi dokumentasi.

Pengamatan atau observasi dalam pengumpulan data dilapangan adalah peran peneliti diketahui dan dalam melakukan pengamatan/ observasi sebagai pengamat. Hal-hal yang diobservasi berkaitan pelaksana sehubungan dengan implementasi kebijakan pemungutan pajak bumi dan bangunan. Selanjutnya kegiatan yang diamati oleh peneliti adalah bagaimana kegiatan petugas yang berkenaan pelaksanaan pemungutan seperti waktu pemungutan, penyampaian surat pemberitahuan pajak terhutang, aktivitas pemungutan pajak bumi dan bangunan seperti verifikasi data wajib pajak melalui surat tanda terima storan, sarana dan prasarana pendukung implementasi kebijakan, pola pendekatan petugas dengan para wajib pajak, program kegiatan dan pengarahan, inisiatif petugas dalam mewujudkan keberhasilan implementasi kebijakan pemungutan pajak bumi dan bangunan. Hal lain yang diamati peneliti adalah bagaimana pembentukan sumberdaya implementasi kebijakan, intensitas koordinasi petugas, program kerja implementasi kebijakan pemungutan pajak bumi dan bangunan serta mengamati bagaimana motivasi dan sikap dukungan petugas dalam aplikasi implementasi kebijakan pemungutan pajak bumi bangunan. Observasi dilakukan di Kantor Dinas Pendapatan Pengelolaan Kekayaan dan Aset Daerah, Kantor 
Pelayanan Pajak Pratama, Kantor Kecamatan Sintang, dan di Kelurahan serta di Desa pada wilayah pemerintahan Kecamatan Sintang.

Wawancara mendalam dalam pengumpulan data dilapangan adalah di buat dalam bentuk terbuka dan terstruktur, membuat catatan wawancara dan selama wawancara peneliti mencatat berbagai informasi yang disampaikan oleh informan, yang berguna untuk menjawab penelitian. Wawancara mendalam digunakan oleh peneliti dengan jenis wawancara tatap muka dengan cara mendatangi rumah informan atau menemui langsung ditempat kerja secara berulang kali yaitu 2 (dua) sampai 4(empat) kali. Ketersedian waktu pelaksanaan wawancara memerlukan waktu 6 (enam) bulan dengan atau tanpa perjanjian lebih dahulu serta dapat dilakukan waktu pagi, sore maupun malam hari, wawancara juga dilakukan lewat telepon. Wawancara secara mendalam dilakukan dengan Bupati, Asisten Bidang Pemerintahan, Kepala Bidang Pendapatan DPPKA, Camat Sintang. Wawancara mendalam juga peneliti lakukan kepada Lurah dan Kepala Desa.

Studi dokumentasi digunakan dalam pengumpulan data adalah menggali data sekunder yang diperlukan untuk menunjang penelitian ini, seperti tentang gambaran umum daerah penelitian. Selain itu studi dokumentasi dilakukan untuk memperoleh dokumen berupa laporan kinerja instani pemerintah yang berkaitan dengan perkembangan data wajib pajak, mutasi objek pajak, dan laporan perkembangan realisasi penerimaan pemungutan bumi dan bangunan. Peneliti lakukan di Dinas Pendapatan Pengelolaan Keuangan dan Aset Daerah Kabupaten Sintang, Kantor Pelayanan Pajak Pratama Kabupaten Sintang, dan Kantor Camat Sintang, Kantor Kelurahan dan Kantor Desa, serta kertas kerja dan blosur yang berkaitan tujuan penelitian.

Metode analisis data yang digunakan dalam penelitian ini adalah metode analisis deskriptif kualitatif, yaitu data yang diolah adalah dalam wujud kata-kata yang telah dikumpulkan dalam aneka macam catatan observasi, wawancara, intisari dokumen, rekaman dan telah diproses sebelumnya melalui pencatatan, pengetikan, penyuntingan atau alih tulis. Kegiatan analisis dilakukan melalui tahapan:reduksi data, penyajian data dan tahapan penarikan kesimpulan/verifikasi.

Tahap pertama reduksi data adalah sebagai proses pemilihan, pemusatan perhatian pada penyederhanaan, pengabstraksian dan data kasar yang muncul dari catatan tertulis dilapangan. Tahap kedua penyajian data yaitu sebagai sekumpulan informasi tersusun yang memberikan kemungkinan adanya penarikan kesimpulan dan pengambilan tindakan. Tahap ketiga adalah menarik kesimpulan dan verifikasi, terhadap arti keteraturan catatan, pola-pola, dan penjelasan dari yang belum jelas meningkat lebih terperinci, yang akan dituangkan pada kesimpulan final.

Penelitian ini dilakukan di Wilayah Kecamatan Sintang Kabupaten Sintang Propinsi Kalimantan Barat. Kecamatan Sintang menjadi lokus atau lokasi penelitian karena beberapa pertimbangan:

(1). Kecamatan Sintang ini dihuni oleh berbagai etnik serta sebagai pusat Ibukota Kabupaten Sintang. Sebagai Ibukota Kabupaten tentu Kecamatan Sintang memiliki keunggulan dan fasilitas yang lebih lengkap dibandingkan dengan Kecamatan lain di wilayah Kabupaten Sintang seperti Kecamatan Sungai Tebelian, Kecamatan Kelam permai, Sepauk, Binjai, Tempunak, Senaning, Merakai, Nanga Ketungau, Kayan Hilir, Kayan Hulu, Serawai dan Kecamatan Ambalau.

(2). Kecamatan ini merupakan salah satu Kecamatan menjadi target penerimaan pajak bumi dan bangunan yang terbesar di Wilayah Kabupaten Sintang, yang dikarenakan memiliki banyak bangunan dan luas wilayah 277,05 $\mathrm{Km}^{2}$ atau 2,43\% (Dua koma empat puluh tiga persen ) dari luas Wilayah Pemerintah Kabupaten Sintang, b). Kecamatan Sintang ini selama 4 (Empat) tahun penerimaan pemungutan pajak bumi dan bangunan belum berhasil sesuai dengan target. 
(3). Kecamatan ini memiliki jumlah penduduk terbesar pertama di Wilayah Pemerintah Kabupaten Sintang, yaitu dengan jumlah penduduk 57.217 jiwa /13.684 Kepala Keluarga yang tersebar pada 6 (Enam) Kelurahan dan 9 (Sembilan) Desa, 26 (Dua puluh enam) Dusun, 202 (Dua ratus dua) Rukun Tetanga dan 28 (Dua puluh delapan) Rukun Warga. Rata-rata laju pertumbuhan penduduk pertahun $3,10 \%$ (Tiga koma sepuluh persen).

(4).Penelitian di Kecamatan Sintang ini tidak dimaksudkan untuk menggeneralisasi temuan yang lingkup lebih luas, melainkan untuk mempelajari realitas pemungutan pajak bumi dan bangunan ditingkat Kecamatan.

\section{HASIL PENELITIAN DAN PEMBAHASAN}

Sehubungan implementasi kebijakan pemungutan pajak di Wilayah Kecamatan Sintang, maka gambaran umum Kecamatan ini adalah secara geografi berbatasan dengan Kecamatan Binjai Hulu, Kecamatan Kelam Permai, Kecamatan Sungai Tebelian, Kecamatan Dedai dan Kecamatan Tempunak. Wilayah Kecamatan Sintang seluas 277,05 $\mathrm{Km}^{2}$ atau 1,28 \% (satu koma dua puluh delapan persen) dari Wilayah Kabupaten Sintang dan Kecamatan Sintang ini sebagai Pusat Ibukota Kabupaten. Luas Wilayah Kecamatan Sintang 1,28 \% (satu koma dua puluh delapan persen), dari luas Wilayah Kabupaten Sintang. Luas Wilayah Kecamatan Sintang ini, seluas $3.502 \mathrm{Ha}$ areal untuk pekarangan, rumah, bangunan dan halaman.

Wilayah Administratif Kecamatan Sintang terdiri dari; 9 (sembilan) Desa dan 6 (enam) Kelurahan, 26 (dua puluh enam) Dusun dan 48 (empat puluh delapan) Rukun Warga serta 202 (dua ratus dua) Rukun Tetangga. Dalam rangka penyelenggaraan pemerintahan Kecamatan, terdapat jumlah pegawai negeri sipil sebanyak 287 (dua ratus delapan puluh tujuh) orang. Dari dua ratus delapan puluh tujuh orang tersebut diketahui bahwa jenjang golongan adalah sebagai berikut: Golongan I sebanyak 2 (dua) orang, Golongan II sebanyak 127 (seratus dua puluh tujuh) orang, Golongan III sebanyak 132 (seratus tiga puluh dua) orang dan Golongan IV sebanyak 26 (dua puluh enam) orang.

Kondisi pegawai negeri sipil berdasarkan jenjang pendidikan sebagai berikut: tingkat sekolah dasar sebanyak 4 (empat) orang, tingkat sekolah lanjutan tingkat pertama sebanyak 15 (lima belas) orang, tingkat sekolah lanjutan atas sebanyak 163 (seratus enam puluh tiga) orang, tingkat diploma sebanyak 60 (enam puluh) orang serta jenjang tingkat pendidikan Sarjana Satu dan Sarjana Dua sebanyak 45 (empat puluh lima) orang, kemudian jumlah pegawai BUMN/BUMD sebanyak 388 (tiga ratus delapan puluh delapan) orang, dan lakilaki sebanyak 299 (dua ratus sembilan puluh sembilan) orang dan perempuan sebanyak 89 (delapan puluh sembilan) orang.

Kondisi penduduk merupakan kelompok sasaran utama yang turut menentukan keberhasilan terimplementasikan kebijakan pemungutan pajak bumi dan bangunan di Wilayah Kecamatan Sintang, dimana penduduk sebagai subyek dan objek pajak,tercatat bahwa penduduk pada tahun 2009 berjumlah 57.217 (lima puluh tujuh ribu dua ratus tujuh belas) jiwa/jumlah kepala keluarga sebanyak 13.684 (tiga belas ribu enam ratus delapan puluh empat) dengan rata-rata jumlah penduduk per-Rt sebanyak 202 (dua ratus dua) jiwa dan kepadatan penduduk per-km² sekitar 207 (dua ratus tujuh) jiwa. Sex atau rasio laki-laki terhadap perempuan sebesar 103 (seratus tiga), rasio tersebut yang nilainya lebih dari seratus menunjukan bahwa jumlah laki-laki lebih banyak dari perempuan.

Kondisi pendidikan penduduk dalam kaitan sebagai sasaran kebijakan pemungutan pajak bumi dan bangunan, ditentukan pula dengan tersediaan sarana dan prasaran pendidikan. Prasarana pendidikan pada Wilayah Kecamatan Sintang sebagai berikut; prasarana Taman Kanak-Kanak sebanyak 23 (dua puluh tiga) sekolah (dua puluh satu TK. Swasta dan dua TK. Negeri), prasarana pendidikan Sekolah Dasar sebanyak 37 (tiga puluh tujuh) Sekolah (tiga puluh SD. Negeri dan tujuh SD.Swasta) prasarana Sekolah Lanjutan Tingkat Pertama sebanyak 15 (lima belas) sekolah (lima 
SMP.Negeri dan sepuluh SMP Swasta). Kemudian prasarana pendidikan Sekolah Lanjutan Tingkat Atas sebanyak 11(sebelas) Sekolah (empat SLTA Negeri dan tujuh SLTA Swasta).

Peran masyarakat dalam penyelenggaraan dan pengelolaan pendidikan cukup besar, yaitu antara lain melalui Yayasan Pendidikan, seperti Yayasan Sukma, Yayasan Muhammadyah, Yayasan Melati Sintang, Yayasan Kapuas Raya, Yayasan Ma'arif, Yayasan Persada Khatulistiwa, Yayasan Nusantara Indah dan Yayasan Suluh Harapan.

Kondisi kesehatan yang turut menentukan perilaku penduduk dalam melakukan berbagai aktivitas, didukung dan ditentukan dengan ketersediaan kondisi sarana dan prasarana pelayanan kesehatan. Prasarana kesehatan yang tersedia di Wilayah Kecamatan Sintang antara lain 1(satu) Rumah Sakit Umum Pemerintah, 1 (satu) Balai Pengobatan, 3 (tiga) Puskesmas dan 14 (empat belas) Polindes. Jumlah tenaga kesehatan mengalami peningkatan dari jumlah semula berjumlah 68 (enam puluh delapan) orang di tahun sebelum menjadi 78 (tujuh puluh delapan) orang. Tenaga Dokter sebanyak 8 (delapan) orang, yang terdiri dari 6 (enam) dokter umum dan 2 (dua) dokter gigi.

Penyelenggaraan pembangunan suatu masyarakat yang berasil, ditentukan pula dengan kondisi keamanan dan ketertiban wilayah. Kondisi keamanan dan ketertiban masyarakat pada Wilayah Kecamatan Sintang cukup aman dan tertib. Kecendrungan terjadi gangguan keamanan dan ketertiban masyarakat antara lain berupa kejahatan dan pelanggaran yang dilaporkan tercatat jumlah kasus yang dilaporkan sebanyak 74 (tujuh puluh empat) kasus terselesaikan 45 (empat puluh lima) kasus, yang belum terselesaikan sebanyak 29 (dua puluh sembilan) kasus. Dominan kasus kejahatan yang terjadi adalah pencurian dan pemberatan (curat) sebanyak 29 (dua puluh sembilan) kasus terselesaikan hanya 9 (sembilan) kasus, kemudian pengelapan dan penipuan 9 (sembilan) kasus dan telah terselesaikan sebanyak 7 (tujuh) kasus, sementara kasus kejahatan yang terkecil adalah kasus perdagangan wanita ( satu kasus dan telah terselesaikan).

Perilaku masyarakat suatu Daerah dalam proses pembangunan ditentukan juga dengan ketaatan warga dalam menjalankan ibadah dan mengamalkan agama yang dianutnya. Kondisi tempat atau rumah ibadah menurut jenis agama tercatat sebagai berikut: tempat Ibadah untuk agama Islam adalah 35 (tiga puluh lima) buah Masjid dan 72 (tujuh puluh dua) buah Surau. Tempat Ibadah untuk agama Katholik adalah 11 (sebelas buah) Gereja dan 2 (dua) buah Kapel. Tempat Ibadah untuk agama Kristen Protestan adalah 17 (Tujuh belas) buah Gereja. Sementara itu tempat Ibadah untuk agama Budha adalah 1 (satu) buah Vihara.

Mengingat implementasi kebijakan pemungutan pajak bumi dan bangunan dapat mempengaruhi kemampuan daya beli rumah tangga warga arau masyarakat, untuk itu perkembangan sosial ekonomi turut menentukan kondisi perubahan-perubahan orientasi nilai kehidupan masyarakat. Kondisi sosial ekonomi masyarakat berdasarkan potensi yang tersedia di ketahui bahwa; tanaman pangan khususnya produksi tanaman padi sebesar 1.5835 (seribu lima ratus delapan puluh lima) ton yang terdiri dari 1.404 (seribu empat ratus empat) ton padi sawah dan 181 (seratus delapan puluh satu) ton padi ladang. Sedangkan untuk tanaman palawija, produksi yang terbesar adalah ubi kayu sebesar 1.173 (seribu seratus tujuh puluh tiga) ton, kemudian ubi jalar dengan produksi 181 (seratus delapan puluh satu) ton dan jagung dengan produksi sebesar 136 (seratus tiga puluh enam) ton.

Hasil perkebunan juga memberikan kontribusi yang besar bagi Kecamatan Sintang terutama produksi tanaman karet, dimana untuk produksi karet mencapai 1.452,64 (seribu empat ratus lima puluh dua koma enam puluh empat) ton dengan luas areal 3.207,00 Ha. Sedangkan tanaman sawit produksi mencapai 3.418,39 (tiga ribu empat ratus delapan belas koma tiga puluh sembilan ) ton dengan luas area 2.530,91 Ha.

Unit usaha industri di Kecamatan Sintang 
terdapat 169 (seratus enam puluh sembilan) unit usaha industri formal, yang terdiri industri kimia agro dan hasil hutan (IKAHH) sebanyak 88 (delapan puluh delapan) unit usaha, dan industri, logam, mesin, elektronik dan aneka (ILMEA) sebanyak 81 (delapan puluh satu) unit usaha, dengan tenaga kerja sebanyak 563 (lima ratus enam puluh tiga) orang yang terdiri dari 379 (tiga ratus tujuh puluh sembilan) tenaga kerja industri IKAHH dan 184 (seratus delapan puluh empat) tenaga kerja industri ILMEA .

Perusahaan perdagangan yang sudah memiliki surat ijin usaha ada 32 (tiga puluh dua) perusahaan perdagangan skala besar, 20 (dua puluh) perusahaan perdagangan skala menengah dan 104 (seratus empat) perusahaan perdagangan skala kecil. Kapasitas tenaga listrik yang dibangkitkan PLN sebanyak 58.042.799 Kwh dengan rincian tenaga yang dijual sebanyak 39.585.487 Kwh, pemakaian oleh PLN sebanyak 202.610 Kwh dan susut trafo/hilang pada transmisi sebanyak 19.151.389 Kwh. Banyaknya pelanggan listrik PLN menurut pelanggan adalah sebagai berikut: untuk rumah tangga sebanyak 14.338 (empat belas ribu tiga ratus tiga puluh delapan) pelanggan, untuk industri dan usaha sebanyak 19.03 (seribu sembilan ratus tiga) pelanggan, untuk badan sosial sebanyak 457 (empat ratus lima puluh tujuh) pelanggan dan instansi pemerintah sebanyak 187 (seratus delapan puluh tujuh) pelanggan

Kecamatan Sintang memiliki 8 (delapan) Perseroan Terbatas (PT), 4 (empat) Koperasi, 34 (tiga puluh empat) Perusahaan Komanditer (CV) dan 318 (tiga ratus delapan belas) Perusahaan perorangan. Pemakaian bahan bakar minyak setiap tahunnya terus mengalami peningkatan, baik untuk konsumsi rumah tangga maupun untuk konsumsi usaha. Pertamina UPMS VI Depot Sintang telah mendistribusikan sebanyaknya 15.963 .000 liter bensin, 13.944.000 liter solar dan 10.705.000 liter minyak tanah.

Kendaraan tercatat sebanyak 16.964 kendaraan bermotor, dengan jumlah terbesar sepeda motor sebanyak 12.887 (75,97\%). Hal ini cukup beralasan mengingat masih kurangnya transportasi roda empat, disamping itu juga sepeda motor banyak digunakan oleh sebagian warga untuk berbagai keperluan. Jumlah penumpang angkutan udara baik yang berangkat maupun yang datang pada Bandar Udara Susilo Sintang ada sebanyak 16 (enam belas) kali penerbangan pesawat.

Sarana pelayanan pendukung komunikasi terdapat 1 (satu) Kantor Pos Induk yang terletak di Kelurahan Tanjungpuri dan 1 (satu) Kantor Pos Pembantu yang terletak di Kelurahan Kanan Hulu dan 1 (satu) Kantor Pos Kecamatan. Volume terhadap penerimaan barang lewat pos tercatat bahwa; surat tercatat sebanyak 4.504 (empat ribu lima ratus empat), surat kilat khusus sebanyak 37.331 (tiga puluh tujuh ribu tiga ratus tiga puluh satu), paket pos sebanyak 2.407 (dua ribu empat ratus tujuh), wesel pos sebanyak 45.397 (empat puluh lima ribu tiga ratus sembilan puluh tujuh).

Berdasarkan data dari sepuluh hotel yang dikumpulkan oleh Biro Pusat Statistik Kabupaten Sintang, persentase tingkat penghunian kamar atau pemakaian kamar malam rata-rata $26,89 \%$ (dua puluh enam koma delapan puluh sembilan persen) dan pemakaian tempat tidur malam rata-rata 25,62 $\%$ (dua puluh lima koma enam puluh dua persen), jumlah malam kamar terpakai sebanyak 26.683 (dua puluh enam ribu enam ratus delapan puluh tiga) kamar. Tamu yang datang seluruhnya merupakan tamu domestik yaitu sebanyak 28.916 (dua puluh delapan ribu sembilan ratus enam belas) orang dalam 1 (satu) tahun.

Kecamatan Sintang terdapat 141 (seratus dua puluh satu) Koperasi, yang terdiri dari 3(tiga) Koperasi Unit Desa ( KUD) dan 118 (seratus delapan belas) Koperasi Simpan Pinjam (Koperasi Non KUD), total anggota untuk koperasi unit desa berjumlah 1.765 (seribu tujuh ratus enam puluh lima) orang dan anggota koperasi simpan pinjam sebanyak 38.588 (tiga puluh delapan ribu lima ratus delapan puluh delapan) orang, dari jumlah koperasi tersebut diketahui bahwa volume usaha Non KUD berjumlah Rp. 141.348.535.000,

Perkembangan harga beberapa komoditi mengalami peningkatan seiring dengan kondisi perekonomian saat ini, walaupun demikian kemampuan daya beli masyarakat masih dapat 
terjangkau. Harga jenis buah-buah berkisar antara Rp.5.000-Rp.20.000, sementara perkembangan harga jenis sayuran berkisar antara Rp.5.000Rp.43.750,. Harga untuk daging tercatat antara Rp.40.000- Rp.80.000. Harga telur berkisar antara Rp.1.500- Rp.2000; Kemudian perkembangan harga susu tercatat antara Rp.6.500- Rp. 42.000. Harga ikan tercatat bahwa jenis ikan berkisar antara Rp.25.000,-Rp.50.000. Harga emas seharga Rp. 245.000,- Rp.280.000,- dan perkembangan harga bahan bangunan untuk pasir pasang seharga Rp.70.000,- kayu belian seharga Rp.165.000,- kayu meranti seharga Rp.65.000,- dan untuk harga semen tiga roda Rp. 73.000,-

Perkembangan penerimaan pajak bumi dan bangunan di Wilayah Kecamatan Sintang, hasil studi dokumen pada Kantor Dinas Pendapatan Pengelolaan Kekayaan dan Aset Daerah Kabupaten Sintang, realisasi penerimaan implementasi kebijakan pemungutan pajak bumi dan bangunan, diperoleh informasi bahwa target sektor perkotaan dan sektor pedesaan selama 4 (empat) tahun selalu meningkat, akan tetapi peningkatan target tersebut dalam implementasi kebijakan pemungutan, realisasi penerimaan tidak pernah mencapai target. Negara Republik Indonesia adalah Negara Hukum berdasarkan Pancasila dan Undang-Undang Dasar 1945 yang menjunjung tinggi hak dan kewajiban setiap orang, oleh karena itu menempatkan perpajakan sebagai salah satu perwujudan kewajiban kenegaraan dalam kegotongroyongan nasional dan peranserta masyarakat dalam membiayai pembangunan.

Sesuai dengan ketentuan Undang-Undang Dasar 1945 itu, maka ketentuan perpajakan yang merupakan landasan pemungutan pajak ditetapkan dengan undang-undang nomor: 12 tahun 1985 tentang pajak bumi dan bangunan yang berlaku sejak tahun 1986 merupakan landasan hukum dalam pengenaan pajak sehubungan dengan hak atas bumi atau perolehan manfaat atas bumi atau kepemilikan, penguasaan atau perolehan manfaat atas bangunan. Setelah hampir satu dasawarsa berlaku undang- undang nomor: 12 tahun 1985, dengan makin meningkat kesejahteraan masyarakat dan meningkat jumlah objek pajak serta menyelaraskan pengenaan pajak dengan amanat dalam perkembangan pembangunan, maka undang-undang nomor: 12 tahun 1985, telah mengalami perubahan melalui undang-undang nomor:12 tahun 1994. Berpegang teguh pada prinsip kepastian hukum dan keadilan, maka arah dan tujuan penyempurnaan undang-undang ini adalah: a). Menunjang kebijaksanaan pemerintah menuju kemandirian bangsa dalam pembiayaan pembangunan yang sumber utama berasal dari penerimaan pajak; b). Lebih memberikan kepastian hukum dan keadilan bagi masyarakat untuk berpartisipasi dalam pembiayaan pembangunan sesuai dengan kemampuannya.

Penyempurnaan undang-undang nomor: 12 tahun 1985 menjadi undang- undang nomor: 12 tahun 1994, dijalaskan bahwa; ketentuan mengenai pajak bumi dan bangunan dilakukan perubahan yang pokok antara lain tercantum sebagai berikut: a). Untuk lebih memberikan keadilan dalam pengenaan pajak, diatur ketentuan mengenai besarnya nilai jual objek pajak tidak kena pajak untuk setiap wajib pajak; b). Memperjelas ketentuan mengenai upaya banding ke badan peradilan pajak. Menurut undang- undang tersebut, dijelaskan bahwa pada hakekatnya, pembayaran pajak bumi dan bangunan merupakan salah satu sarana perwujudan kegotongroyongan Nasional dalam pembiayaan Negara dan pembangunan Nasional, sehingga dalam pengenaannya harus memperhatikan prinsip kepastian hukum, keadilan, dan kesederhanaan serta ditunjang oleh sistem administrasi perpajakan yang memudahkan wajib pajak dalam memenuhi kewajiban pembayaran pajak.

Pajak bumi dan bangunan adalah pajak Negara yang sebagian besar penerimaan itu merupakan pendapatan Daerah yang antara lain dipergunakan untuk penyediaan fasilitas umum yang juga dinikmati oleh pemerintah Pusat dan pemerintah Daerah. Oleh sebab itu wajar pemerintah Pusat juga ikut membiayai penyediaan fasilitas tersebut melalui pembayaran pajak bumi dan bangunan. Lebih lanjutmMengenai bumi dan 
bangunan yang dimiliki perorangan dan/atau badan yang digunakan oleh Negara, kewajiban perpajakannya tergantung pada perjanjian yang diadakan. Peraturan Menteri Keuangan nomor: 516/KMK.04/2000 dan nomor: 86/PMK.03/2006 tentang tata cara penentuan besarnya nilai perolehan ojek pajak tidak kena pajak bea perolehan hak atas tanah dan bangunan, ditetapkan bahwa bahwa besarnya nilai perolehan ojek pajak tidak kena pajak bea perolehan hak atas tanah bangunan paling rendah adalah Rp. 300.000 (tiga ratus ribu rupiah) dan paling tinggi adalah $\mathrm{Rp}$. 60.000 .000 (enam puluh juta rupiah).

Tindak lanjut terhadap pengenaan pajak bumi dan bangunan, oleh Direktur Jenderal Pajak dengan Peraturan nomor: 6/PJ/2008 tentang tata cara pengurangan denda administrasi pajak bumi dan bangunan, telah ditetapkan bahwa pengurangan pembayaran pajak bumi dan bangunan sebagai sarana perwujudan kegotongroyongan dalam pembiayaan pembangunan Nasional dengan pengenaannya memperhatikan prinsip kepastian hukum dalam pajak, oleh pemerintah diatur antara lain bahwa: permintaan pengurangan denda administrasi dapat dilakukan untuk wajib pajak orang pribadi, wajib pajak orang pribadi secara kolektif dan wajib pajak badan. Wajib pajak orang pribadi yang mengalami kesulitan keuangan atau wajib pajak badan yang mengalami kesulitan likuiditas. Penetapan dendan administrasi sebesar dua puluh lima persen dihitung dari pokok pajak yang tercantum surat keterangan pajak pajak bumi dan bangunan serta denda administrasi sebesar $2 \%$ (dua persen) sebulan.

Penyesuaian perkembangan terhadap nilai jual objek pajak tidak kena pajak di Kabupaten Sintang ditetapkan melalui Keputusan Menteri Keuangan Republik Indonesia nomor: Kep-085/ WPJ.13/BD.03/2009 tanggal 31 desember 2009 tentang penetapan besarnya nilai jual objek pajak tidak kena pajak sebagai dasar penghitungan pajak bumi dan bangunan Kabupaten Sintang ditetapkan sebesar Rp. 4.000 .000 (empat juta rupiah) untuk setiap wajib pajak. Penetapan NJOPTKP dalam undang-undang nomor: 12 tahun 1994 adalah sebesar Rp. 8.000.000 untuk setiap wajib pajak, dengan diberlakukan penyesuaian NJOPTKP Rp. 4.000.000 untuk setiap wajib pajak ini, berarti beban pajak yang harus ditanggung oleh wajib pajak menjadi lebih besar, sehingga besarnya penerimaan pajak bumi dan bangunan akan semakin besar atau meningkat.

Penjelasan mengenai objek pajak dalam undang-undang nomor: 12 tahun 1994 tentang pajak bumi dan bangunan, adalah sebagai berikut: Obyek pajak yang tidak dikenakan pajak bumi dan bangunan adalah objek pajak yang digunakan: a). untuk melayani kepentingan umum di bidang ibadah, sosial, kesehatan, pendidikan dan kebudayaan nasional, yang tidak dimaksudkan untuk memperoleh keuntungan, b). untuk kuburan, peninggalan purbakala, atau yang sejenisnya, c). merupakan hutan lindung, hutan suaka alam, hutan wisata, taman nasional, tanah pengembalaan yang dikuasai oleh Desa, dan tanah Negara yang belum dibebani suatu hak, d). digunakan oleh perwakilan diplomatik, konsulat berdasarkan asas perlakuan timbal balik, e). digunakan oleh badan atau perwakilan organisasi yang ditentukan oleh menteri keuangan. Kemudian objek pajak yang digunakan oleh Negara untuk penyelenggaraan pemerintahan, penentuan pajak diatur lebih lanjut dengan peraturan pemerintah. Dalam undang-undang nomor: 28 Tahun 2009 tentang pajak Daerah dan retribusi Daerah di jelaskan bahwa pajak bumi dan bangunan dikategorikan sektor perdesaan dan sektor perkotaan.

Pajak bumi dan bangunan perdesaan dan perkotaan adalah pajak atas bumi dan/atau bangunan yang dimiliki, dikuasai, dan/atau dimanfaatkan oleh orang pribadi atau badan, kecuali kawasan yang digunakan untuk kegiatan usaha perkebunan, perhutanan, dan pertambangan. Kemudian bumi adalah permukaan bumi yang tanah dan perairan pedalaman serta laut Wilayah Kabupaten/Kota. Bangunan adalah konstruksi teknik yang ditanam atau dilekatkan secara tetap pada tanah dan/atau perairan pedalaman dan/atau laut. Termasuk dalam pengertian bangunan adalah : a). Jalan lingkungan yang terletak dalam satu 
kompleks bangunan seperti hotel, pabrik, dan emplasemennya, yang merupakan suatu kesatuan dengan kompleks bangunan tersebut, b). Jalan tol, c). Kolam renang, d). Pagar mewah, e). Tempat olahraga, f).Galangan kapal, dermaga, g). Taman mewah, h). Tempat penampungan/kilang minyak, air dan gas, pipa minyak dan i). Menara.

Subjek pajak bumi dan bangunan adalah orang pribadi atau badan yang secara nyata mempunyai suatu hak atas bumi dan/atau memperoleh manfaat atas bumi, dan/atau memiliki, menguasai, dan/atau memperoleh manfaat atas bangunan. sedangkan wajib pajak adalah orang pribadi atau badan, meliputi pembayar pajak, pemotongan pajak, dan pemungut pajak yang mempunyai hak dan kewajiban perpajakan sesuai dengan ketentuan peraturan perundang-undangan perpajakan daerah. Pemungutan adalah suatu rangkaian kegiatan mulai dari perhimpunan data objek dan subjek atau retribusi, penentuan besarnya pajak atau retribusi yang terhutang sampai kegiatan penagihan pajak atau retribusi kepada wajib pajak atau wajib retribusi serta pengawasan penyetorannya.

Kebijakan yang berhubungan dengan objek pajak dan wajib pajak, oleh pemerintah dikenal dengan ketentuan Surat Pemberitahuan Objek Pajak (SPOP), SPOP ini adalah surat yang digunakan oleh wajib pajak untuk melaporkan data subjek dan objek pajak bumi dan bangunan perdesaan dan perkotaan sesuai dengan ketentuan peraturan perundang-undangan perpajakan Daerah. Kemudian ketentuan dalam penetapan pajak di kenal dengan Surat Pemberitahuan Pajak Terutang (SPPT), SPPT ini adalah surat yang digunakan untuk memberitahukan besarnya pajak bumi dan bangunan perdesaan dan perkotaan yang terutang kepada wajib pajak.

Peran penting aspek interpretasi atau penafsiran dalam implementasi kebijakan meliputi aktivitas ketentuan program kegiatan dan aktivitas pengarahan yang dapat diterima atau layak dilaksanakan. Kebijakan yang diimplementasikan dengan baik dan tepat, hendaknya didukung oleh ketersediaan arahan serta petunjuk dalam mengimplementasikannya. Arahan dan petunjuk itu tidak hanya diterima tetapi juga harus jelas, arah dan tujuan yang ingin dicapai. Arah dan tujuan yang ingin dicapai dalam implementasi kebijakan dimaksudkan agar para petugas tidak berlawanan arah, apabila arahan dan tujuan tidak jelas, para petugas pelaksana akan kebingungan. Kebingungan para pelaksana menimbulkan interpretasi/penafsiran yang berbeda tentang apa yang seharusnya mereka kerjakan atau yang mereka lakukan dan pada akhirnya mereka akan mempunyai kebijakan tersendiri dalam memandang penerapan kebijakan tersebut, sehingga berdampak pada pandangan yang berbeda dengan pandangan dari yang membuat kebijakan.

Interpretasi atau penafsiran dalam implementasi kebijakan memegang peranan penting agar tidak terjadi kerancuan dalam mengimplementasikan kebijakan. Penafsiran dalam implementasi kebijakan adalah pemahaman yang baik terhadap sesuatu hal yang harus dikerjakan atau dilakukan dalam implementasi kebijakan. Aspek interpretasi atau penafsiran petugas terhadap kegiatan kebijakan yang diimplementasikan, hasil penelitian melalui penelusuran dokumen pemungutan pajak bumi dan bangunan pada Kantor DPPKA, diperoleh informasi bahwa kebijakan pemungutan pajak bumi dan bangunan di Wilayah Kabupaten Sintang telah dituangkan dalam Peraturan Bupati nomor: 15 tahun 2009 tentang petunjuk pelaksanaan tata cara penyampaian surat pemberitahuan pajak terhutang, penagihan dan pembayaran serta pelaporan pajak bumi dan bangunan di Kabupaten Sintang. Peraturan Bupati tersebut dijelaskan bahwa mekanisme implementasi kebijakan pemungutan pajak bumi dan bangunan, yaitu: (1). Untuk meningkatkan pengelolaan pajak bumi dan bangunan di Kabupaten Sintang sehingga dapat berdaya guna dan berhasil guna dalam menunjang pembangunan daerah, maka perlu ditetapkan standarisasi dalam hal penyampaian surat pemberitahuan pajak terhutang, penagihan/ pembayaran serta pelaporannya di Kabupaten Sintang. (2). Tata cara Penyampaian Surat 
Pemberitahuan Pajak Terhutang pajak bumi dan bangunan (SPPT-PBB) di Kabupaten Sintang diserahkan oleh Dinas Pendapatan Pengelolaan Keuangan dan Aset Daerah (DPPKA) kepada Camat dengan dilengkapi berita acara (BA) penyerahan selanjutnya Camat menyerahkan ke Lurah/Kepala Desa dengan dilengkapi berita acara (BA) penyerahan, yang ditanda tangan oleh unsur DPPKA, Camat, Lurah dan Kepala Desa sebagai penerima. (3).Penyampaian surat pemberitahuan pajak terhutang pajak bumi dan bangunan kepada petugas penyampai oleh Lurah/Kepala Desa disertai dengan surat penunjukan. Penyampaian SPPT- PBB kepada wajib pajak dilaksanakan selambat-lambatnya 20 (dua puluh) hari sejak tanggal diterimanya SPPT-PBB dari DPPKA Kabupaten Sintang, kemudian penyampaian itu dilakukan secara serentak dalam satu wilayah Kecamatan, Kelurahan dan Desa. (4). Penagihan atau pemungutan pajak bumi dan bangunan dilakukan oleh petugas pemungut yang ditunjuk oleh Lurah/ Kepala Desa dengan Keputusan Lurah/ Kepala Desa. Tata kerja penagihan atau pemungutan pajak bumi dan bangunan disesuaikan dengan ketentuan, bahwa petugas pemungut seminggu sekali melaporkan perkembangan penyampaian SPPT-PBB dalam wilayah kerjanya kepada Lurah/Kepala Desa. Selanjutnya Lurah/ Kepala Desa membuat laporan mingguan perkembangan penyampaian SPPT-PBB dan laporan mingguan penerimaan pajak bumi dan bangunan kepada Camat dengan tembusan kepada DPPKA Kabupaten Sintang. (5). Camat setiap akhir bulan membuat laporan perkembangan penyampaian SPPT-PBB dan rekapitulasi laporan penerimaan bulanan pajak bumi dan bangunan kepada ketua Tim Intensifikasi atau Bupati Kabupaten Sintang dengan tembusan kepada DPPKA dan Kantor Pelayanan Pajak Pratama (KPP. Pratama) Sintang. DPPKA membuat laporan bulanan perkembangan penyampaian SPPT-PBB dan membuat laporan penerimaan bulan pajak bumi dan bangunan dalam wilayah kerjanya kepada Bupati dan tembusannya KPP. Pratama. KPP.Pratama selambatnya-lambatnya tanggal 10 (sepuluh ) bulan berikutnya, dengan tembusan kepada Tim Intensifikasi pajak bumi dan bangunan Propinsi Kalimantan Barat. (6). Konfirmasi atau pencocokan data yang berkaitan dengan surat tanda terima setoran (STTS) dapat dilakukan sebelum maupun sesudah jatuh tempo. Pencocokan STTS sebelum jatuh tempo dapat dilakukan 3 (tiga) bulan atau 15(lima belas) hari menjelang jatuh tempo. Pelaksanaan pencocokan STTS dilakukan oleh pihak KPP.Pratama, DPPKA dan petugas tempat pembayaran. (7). Keberatan dan pengurangan pajak bumi dan bangunan dapat diajukan oleh wajib pajak dikarenakan pajak terhutang pada SPPT-PBBnya tidak sesuai dengan keadaan sebenarnya. Hal ini terjadi karena adanya beberapa kesalahan seperti : a) Kesalahan pada luas objek pajak, b) Kesalahan klasifikasi objek, baik untuk kelas jalan atau kelas bangunan yang dirasakan terlalu tinggi, c) Kesalahan pada penetapan /pengenaan pajak terhutang. Kelengkapan administrasi dalam rangka pengajuan keberatan adalah disertai dengan: a). Bukti pemilikan hak atas tanah (sertifikat), b). Akta jual beli, c). Izin mendirikan bangunan (IMB) atau d). Bukti resmi lainnya. (8). Pengajuan pengurangan dapat dilakukan selambatnya 60 (enam puluh) hari sejak diterimanya SPPT-PBB oleh wajib pajak. Pengajuan pengurangan yang disebabkan bencana alam dan sebagainya dapat diajukan oleh Lurah/ Kepala Desa setempat selambat-lambatnya 60 (enam puluh) hari sejak terjadinya bencana alam atau sebab luar biasa lainnya. Proses pengajuan keberatan dan pengurangan ini dibuat dalam bentuk surat permohonan yang ditujukan kepada KPP.Pratama dengan tembusan DPPKA, baik secara individu/perorangan maupun secara kolektif melalui Lurah/Kepala Desa yang bersangkutan dan diketahui Camat. (9). Penerapan sanksi bagi wajib pajak pada SPPT telah dicantumkan tanggal jatuh tempo pembayaran, apabila wajib pajak melakukan pembayaran setelah lewat tanggap jatuh tempo akan dikenakan denda/sanksi administrasi sebesar dua persen setiap bulannya untuk jangka waktu paling lama 24 (dua puluh empat) bulan. Bagi wajib pajak jumlah pajak terhutang berdasarkan 
Surat Tagihan Pajak (STP) yang tidak bayar, dapat ditagih dengan surat paksa. Jika pajak bumi dan bangunan tidak dibayar oleh wajib pajak, maka akan dilakukan penyitaan terhadap objek pajak sesuai dengan jumlah pajak terhutang yang bersangkutan. (10). Kelalaian petugas pemungut tidak menyetor pajak bumi dan bangunan hasil tagihan dari wajib pajak ketempat pembayaran yang telah ditunjuk (Bank atau Camat setempat) dikenakan sanksi sesuai dengan ketentuan hukum yang berlaku.

Berpedoman pada ketentuan di atas, dalam implementasi kebijakan pemungutan pajak bumi dan bangunan, oleh peneliti dapat dipersepsikan bahwa: aktivitas kegiatan aspek interpretasi atau penafsiran dalam implementasi kebijakan telah dibuat dan ditetapkan secara baik dan layak dilaksanakan, hal ini terlihat dan terangkum pada isi kebijakan itu yang telah menetapkan hak dan kewajiban petugas dan hak serta kewajiban wajib pajak bumi dan bangunan. Ketentuan kegiatan dalam implementasi kebijakan pemungutan pajak bumi dan bangunan sebagai acuan tentang mekanisme dan tahapan program kegiatan implementasi kebijakan, terdiri dari: (1).Tujuan yang ingin dicapai. (2). Tatacara penyampaian surat pemberitahuan pajak terhutang. (3). Waktu penyampaian surat pemberitahuan pajak terhutang kepada petugas dan waktu petugas menyampaikan kepada wajib pajak. (4).Tatacara waktu penagihan. (5). Kewajiban membuat laporan perkembangan. (6). Konfirmasi data surat tanda terima setoran. (7). Batas waktu penyampaian keberatan dan pengurangan yang diajukan oleh wajib pajak. (8). Penerapan sanksi kepada wajib pajak sudah jatuh tempo. (9). Sanksi kelalaian petugas menyetorkan pemungutan pajak bumi dan bangunan.

Aspek interpretasi atau penafsiran yang meliputi aktivitas program kegiatan dalam implementasi kebijakan sebagaimana yang telah dikemukakan di atas. Realita di lapangan setelah dikonfirmasikan langsung melalui hasil wawancara diperoleh gambaran, sebagai berikut: Penafsiran terhadap program kegiatan oleh petugas pelaksana adalah melaksanakan tugas sesuai dengan fungsi, kemudian perlu motivasi melalui insentif untuk pelaksanaan operasional dan melaksanakan tugas penuh dengan tanggungjawab. Kemudian penafsiran para pelaksana cukup baik, dalam arti bahwa pelaksana dilapangan hanya bertugas menyampaikan surat pemberitahuan pajak terhutang kepada wajib pajak dan menerima pengembalian surat pemberitahuan pajak terhutang dari wajib pajak, dalam rangka memonitor surat tanda terima storan pajak bumi dan bangunan.

Argumentasi dari Tim Intensifikasi tersebut oleh peneliti dapat dipersepsikan bahwa aspek interpretasi/penafsiran terhadap aktivitas program kegiatan oleh petugas dalam mengimplementasi kebijakan pemungutan pajak dan bangunan sudah baik sehingga mereka dapat melaksanakan tugas dan fungsinya. Interpretasi atau penafsiran terhadap program kegiatan dalam implementasi kebijakan pemungutan pajak bumi dan bangunan di Wilayah Kecamatan Sintang, oleh petugas Kecamatan dan petugas Kelurahan menyampaikan argumentasi yang berbeda dengan Tim Intensifikasi. Penafsiran tentang program kegiatan yang lebih baik dari para pelaksana adalah sistem perlu dirubah karena masih banyak kendala dan birokrasi yang membingungkan para pengelola petugas pemungut pajak. Sebaiknya perlu ditetapkan satu orang petugas untuk mengelola semua jenis perpajakan di tingkat Kecamatan, Kelurahan dan Desa, dengan demikian tidak ada lagi petugas pajak bumi dan bangunan yang merangkap dengan pekerjaan lain, sehingga terfokus kepada pengelola pemungutan pajak, begitu pula ditingkat Kabupaten, disarankan dikelola oleh Dinas khusus serta Bank hanya untuk menyimpan bukan untuk menerima langsung dari objek wajib paja bumi dan bangunan. Penafsiran tentang program kegiatan dalam implementasi kebijakan pemungutan pajak bumi dan bangunan harus di dukung dengan perubahan sistem pelayanan birokrasi serta tersedianya petugas khusus baik di tingkat Kecamatan, Kelurahan maupun di tingkat Desa yang menangani implementasi kebijakan pemungutan pajak bumi dan bangunan. Penafsiran terhadap program kegiatan yang baik harus dilakukan dengan 
akuratnya data yang ada, yaitu dengan melakukan pendataan ulang setiap satu tahun, kemudian petugas haruslah menguasai wilayah jangkauan dalam melakukan pemungutan pajak bumi dan bangunan. Argumentasi petugas Kelurahan di atas, menggambarkan bahwa interpretasi atau penafsiran terhadap program kegiatan akan lebih baik apabila di dukung akurat data wajib pajak dan penguasaan wilayah jangkuan pemungutan pajak bumi dan bangunan.

Perbedaan pandangan tentang interpretasi atau penafsiran tentang aktivitas program kegiatan dalam implementasi kebijakan pemungutan pajak bumi dan bangunan antara Tim Intesifikasi dengan petugas Kecamatan dan petugas Kelurah, pada prinsipnya adalah sebagai saran untuk menonjolkan letak penting program kegiatan yang didukung dengan peran petugas dalam implementasi kebijakan pemungutan pajak bumi dan bangunan. Tujuan dari argumentasi tersebut oleh peneliti dapat dipandang dengan bertujuan sebagai berikut: Interpretasi atau penafsiran terhadap aktivitas program kegiatan dalam implementasi kebijakan pemungutan pajak bumi dan bangunan oleh petugas akan makin baik, maka petugas sebaiknya tidak merangkap pekerjaan sehingga interpretasi atau penafsiran terhadap program kegiatan sebagai suatu beban dan tanggungjawab kegiatan dapat berjalan secara fokus dan maksimal serta petugas menjalankan tugas menjadi lebih baik dan lebih terarah. Kemudian aktivitas program kegiatan dalam implementasi kebijakan dapat terimplementasi secara baik, maka memerlukan validasi data wajib pajak yang akurat dan kegiatan sosialisasi Tim Intesifikasi kepada wajib pajak.

Aktivitas pengarahan penyampaian informasi program kegiatan dalam implementasi kebijakan kepada petugas, hasil wawancara dengan anggota Tim Intensifikasi menyatakan bahwa: Pengarahan dalam bentuk penyampaian informasi tentang program kegiatan secara teknis dilakukan oleh Dinas Pendapatan Pengelolaan Kekayaan dan Asset Daerah bersama Kantor Pelayanan Pajak Pratama. Bentuk arahan melalui penyuluhan terpadu pada tiap Kecamatan, tetapi belum ditindaklanjuti sampai pada tingkat Kelurahan dan Desa. Petugas pemungut dilapangan dilakukan oleh tingkat Kelurahan dan Desa arahan kepada petugas hanya untuk menyampaikan surat pemberitahuan pajak terhutang sesuai dengan waktu yang ditentukan. Bentuk penyampaian informasi program kegiatan dilakukan secara terpadu hanya kepada Kecamatan, sedangkan petugas Kelurahan dan Desa arahan itu hanya untuk menyampaikan surat pemberitahuan pajak terhutang kepada wajib pajak.

Tindak lanjut bentuk aktivitas pengarahan informasi program kegiatan dalam implementasi kebijakan kepada petugas pemungut, hasil wawancara dengan petugas Kelurahan dinyatakan bahwa: Bentuk penyampaian arahan yang disampaikan tidak focus, sehingga sedikit perhatian tentang informasi program kegiatan mengimplementasikan kebijakan pemungutan pajak bumi dan bangunan di Wilayah Kelurahan. Pendapat petugas Kelurahan menggambarkan bahwa informasi program kegiatan yang mereka terima tidak focus sehingga pemahaman mereka terhadap isi program kegiatan dalam implementasi kebijakan tidak lengkap. Senada dengan pendapat petugas Kelurahan tentang informasi program kegiatan, hasil wawancara dengan petugas Desa mengemukakan bahwa: Penafsiran terhadap pengarahan tentang program kegiatan dalam implementasi kebijakan pemungutan pajak bumi dan bangunan, yang dianggap belum maksimal adalah mekanisme perhitungan dan penetapan beban objek pajak serta jumlah kewajiban pajak bumi dan bangunan yang harus dibayarkan. Bentuk pengarahan informasi program kegiatandalam implementasi kebijakan yang disampaikan kepada petugas kurang focus sehingga perhatian petugas terhadap informasi tidak menghasilkan pemahaman yang baik atau masih rendah. Bentuk pengarahan tidak didukung dengan kemampuan mengkomunikasikan arahan yang rinci terutama yang berkaitan dengan mekanisme perhitungan dan penetapan beban objek pajak serta jumlah kewajiban pajak bumi dan bangunan yang harus dibayarkan. 
Aspek interpretasi atau penafsiran pengarahan informasi program kegiatan kepada petugas belum termuat uraian tentang hal yang berkenaan dengan keterlibatan para wajib pajak agar melaporkan mutasi objek dan subyek pajaknya. Bentuk penyampaian arahan akan informasi program kepada petugas belum didukung dengan pedoman petunjuk teknis yang berkenaan dengan mekanisme perhitungan dan penetapan beban pajak bumi dan bangunan. Aktivitas pengarahan informasi program kegiatan dalam bentuk standar ukuran dasar implementasikan kebijakan pemungutan pajak bumi dan bangunan, hasil wawancara dengan Tim Intensifikasi menyatakan bahwa: Ukuran dasar tentang pajak bumi dan bangunan adalah penetapan nilai jual objek pajak, setelah mendapat persetujuan dari Bupati, yang tiap tahunnya ditentukan melalui peraturan Bupati yang dilaksanakan oleh Dinas Pendapatan Pengelolaan Kekayaan dan Asset Aaerah. Kemudian standar ukuran dasar yang harus dicapai adalah penerimaan menimal $75 \%$ dari target yang telah ditetapkan dan yang harus diselesaikan dalam batas waktu bulan Oktober secara serempak di Wilayah Kabupaten.

Argumentasi Tim Intensifikasi menyatakan bahwa standar ukuran dasar program kegiatan ditetapkan bahwa batas waktu pembayaran atau surat tanda terima setoran pajak bumi dan bangunan adalah bulan oktober dan standar menimal pencapaian penerimaan adalah $75 \%$ (tujuh puluh lima persen) dari target yang ditetapkan. Interpretasi atau penafsiran pengarahan standar ukuran dasar program kegiatan dalam implementasi kebijakan pemungutan pajak bumi dan bangunan. Perlu dilakukan pendataan kepada wajib pajak yang akurat, adanya dukungan dari wajib pajak dan seluruh elemen masyarakat tentang kewajiban membayar pajak bumi dan bangunan secara tepat waktu. Pendapat petugas Kelurahan itu menggambarkan bahwa target penerimaan akan mudah tercapai apabila didukung akurat data alamat wajib pajak dan kesadaran wajib pajak membayar kewajiban tepat waktu. Pendapat senada juga disampaikan oleh petugas Desa. Ukuran dasar program kerja yang harus dicapai adalah menimal antara tujuh puluh persen sampai dengan tujuh puluh lima persen dari target yang ditetapkan, dan tentang objek pajak ganda dan alamat tinggal wajib pajak harus diperjelas dan di data kembali. Interpretasi atau penafsiran petugas terhadap pengarahan ukuran dasar program kegiatan yang harus dicapai sudah baik dan benar. Interpretasi atau penafsiran terhadap pengarahan tujuan dan maksud mengimplementasikan kebijakan pemungutan pajak bumi dan bangunan, secara umum oleh petugas Kecamatan, Kelurahan dan petugas Desa telah memahami.

Wujud pemahaman petugas tentang pengarahan dalam implementasi kebijakan adalah mereka menjalankan kegiatan telah sesuai dengan tugas sebagai pelaksana penyampai surat pemberitahuan pajak terhutang serta sebagai pemungut pajak bumi dan bangunan di Wilayahnya masing-masing. Kemudian petugas harus terlibat dalam bentuk pendataan ulang wajib pajak untuk memperoleh data yang akurat, aktivitas itu berupa pendataan pencocokan kondisi alamat wajib pajak yang tersesuaikan dengan surat pemberitahuan pajak terhutang. Interpretasi atau penafsiran petugas terhadap bidang tugas dalam implementasikan kebijakan pemungutan pajak bumi dan bangunan, hasil wawancara dengan Tim Intensifikasi menyatakan bahwa: Petugas pelaksana pemungutan pada umumnya memiliki kemampuan untuk kegiatan pemungutan tersebut, namun perlu dukungan sarana penunjang lapangan yang memadai serta ketersediaan insentif yang cukup, kedepan dipandang perlu di optimalkan lagi melalui petugas khusus sebagai petugas yang menangani pajak bumi dan bangunan baik ditingkat Kabupaten, Kecamatan, Kelurahan dan maupun tingkat Desa.

Argumentasi Tim Intensifikasi secara umum berpendapat bahwa petugas memiliki kemampuan, akan tetapi kemampuan tersebut dipandang perlu dilakukan menyediakan petugas khusus yang disertai dengan penyediaan sarana dan prasaran serta insentif yang memadai. Pendapat yang senada dengan Tim Intensifikasi, Tugas yang 
telah diberikan kepada pemungut pajak tidaklah sesuai dengan bidangnya, namun melihat hasilnya selama ini para petugas pemungut pajak bumi dan bangunan sudah sangat maksimal dalam melaksanakan tugas dan tanggungjawabnya. Berpijak pada argumentasi di atas, serta hasil penelitian melalui observasi pada Kelurahan dan Desa, oleh peneliti dapat dijelaskan bahwa interpretasi atau penafsiran petugas terhadap bidang tugas aktivitas program kegiatan dalam implementasi kebijakan adalah sebagai berikut: interpretasi atau penafsiran terhadap bidang tugas dalam implementasi kebijakan pemungutan pajak bumi dan bangunan yang dianggap sudah baik dan sudah memuaskan terlihat hal sebagai berikut: a). Interpretasi atau penafsiran akan pengarahan kerja seperti penyampaian surat pemberitahuan pajak terhutang kepada wajib pajak. b). Interpretasi atau penafsiran tentang penetapan target dan upaya pencapaian penerimaannya. c). Interpretasi atau penafsiran tentang usaha maksimal dalam pencapaian realisasi penerimaan mendekati target. f). Interpretasi atau penafsiran tentang standar ukuran pencapaian target. g). Interpretasi atau penafsiran dalam melakukan tagihan kerumahrumah. h). Interpretasi atau penafsiran dalam melakukan pemungutan dengan istilah gerakan sapu sisir.

Interpretasi atau penafsiran oleh petugas dalam implementasi kebijakan yang dianggap belum memuaskan adalah: interpretasi atau penafsiran tentang besaran penetapan perhitungan target penerimaan pajak bumi dan bangunan serta interpretasi atau penafsiran terhadap penetapan nilai jual objek pajak dan interpretasi atau penafsiran mereka tentang dasar penerbitan surat pemberitahuan pajak terhutang. Aktivitas komunikasi penyampaian informasi program kegiatan dalam implementasi kebijakan pemungutan pajak bumi dan bangunan kepada petugas, hasil wawancara dengan anggota Tim Intensifikasi terangkum sebagaimana dikemukakan bahwa: Bentuk komunikasi pengarahan informasi program kegiatan dalam implementasi kebijakan pemungutan pajak bumi dan bangunan kepada para petugas melalui komunikasi lisan dan tertulis melalui surat perintah atau edaran, melaksanakan kegiatan dengan tatap muka langsung dengan pimpinan satuan kerja perangkat daerah dan membuat petunjuk pelaksana serta petunjuk teknis pajak bumi dan bangunan, akan tetapi pengarahan dengan komunikasi langsung kepada petugas pemungut di lapangan belum memuaskan atau optimal. Pengarahan dan komunikasi dilakukan oleh Tim Intensifikasi hanya dengan pihak Kecamatan, yang selanjutnya Kecamatan yang berkewajiban untuk menyampaikan kepada petugas Kelurahan dan petugas Desa.

Argumentasi dari Tim Intensifikasi, menjelaskan bahwa; komunikasi pengarahan secara umum dilakukan melalui surat edaran dan surat perintah, sedangkan komunikasi langsung dengan melakukan tetap muka dengan petugas Kelurahan dan Desa belum dilakukan secara maksimal. Tindak lanjut interpretasi atau penafsiran petugas terhadap bentuk pengarahan itu, oleh Tim Intensifikasi dikatakan bahwa: (1).Ketepatan petugas menafsirkan tugas kegiatan dalam mengimplementasikan kebijakan pemungutan pajak bumi dan bangunan, terkadang masih belum tepat atau salah menerbitkan surat pemberitahuan pajak terhutang terhadap wajib pajak sebagai dasar pemungutan pajak bumi dan bangunan, (2). Ketepatan petugas menafsirkan kegiatan yang harus dilakukan terutama tentang laporan ketidakkecocokan alamat wajib pajak serta adanya penetapan obyek dan subyek pajak yang ganda dan wajib pajak yang merasa keberatan dalam membayarkan pajaknya belum optimal dan laporan belum tepat waktu.

Pendapat Tim Intensifikasi menyatakan bahwa penafsiran petugas di lapangan masih belum tepat, sehingga terjadi kekeliruan dalam menerbitkan surat pemberitahuan pajak terhutang, ketidak-kecocokan data alamat wajib pajak dan terdapat penghitungan objek dan subyek pajak yang ganda serta petugas belum melakukan rutinitas pelaporan perkembangan wajib pajak baru. Pendapat yang senada dengan yang disampaikan oleh Tim Intensifikasi, setelah dilakukan konfirmasi 
dengan petugas Kelurahan dan Desa. Diakui bahwa bentuk dalam komunikasi lisan tentang arahan informasi yang diterima dianggap masih kurang, sementara bagian yang menangani bidang tugas pemungutan pajak bumi dan bangunan tidak didukung oleh ketersediaan staf. Pemahaman akan informasi kerja melalui surat edaran hanya sebatas pemahaman untuk menyampaikan surat pemberitahuan pajak terhutang dan surat tanda terima storan. Arahan dalam bentuk komunikasi lisan belum maksimal. Pendapat petugas Kelurahan dan petugas Desa tersebut di atas, oleh peneliti dapat dipersepsikan bahwa: aktivitas komunikasi dalam pengarahan atau penyampaian informasi program kegiatan dalam implementasi kebijakan belum didukung oleh pertemuan rutin serta belum didukung dengan sosialisasi peran petugas pemungut pada tingkat Kelurahan dan Desa, sehingga interpretasi atau penafsiran petugas terhadap pemahaman tugas dalam penyelesaian masalah keberatan wajib pajak dan pelaporan perkembangan wajib pajak baru masih kurang.

Aktivitas kewenangan bagian dalam memberikan pengarahan dan perintah dalam implementasi kebijakan, hasil wawancara dengan anggota Tim Intensifikasi terangkum sebagaimana yang dikemukakan berikut ini: Kewenangan utama memberikan arahan adalah Dinas Pendapatan Pengelolaan Kekayaan dan Asset Daerah sebagai unit pemungut pendapatan sektor pajak bumi dan bangunan. Kewenangan ini masih terbatas, yaitu sebatas untuk menyampaikan surat pemberitahuan pajak terhutang kepada wajib pajak sesuai dengan jadual yang telah ditentukan, Sementara kewenangan untuk memonitor perkembangan tentang pelunasan pajak bumi dan bangunan melalui surat tanda terima storan, bukan menjadi kewenangan petugas pemungut dilapangan. Kewenangan tugas pemungut dilapangan hanya menyampaikan surat pemberitahuan pajak terhutang.

Pendapat Tim Intensifikasi itu dapat disimpulkan bahwa kewenangan dalam memberikan arahan adalah DPPKA berupa kewenangan untuk menerbitkan dan menyampaikan surat pemberitahuan pajak terhutang sesuai jadual yang telah ditentukan serta mencocokan surat tanda terima setoran. Kewenangan petugas pemungut dilapangan adalah menyampaikan surat pemberitahuan pajak terhutang serta memonitor perkembangan penyampaian surat pemberitahuan itu kepada wajib pajak di Wilayah kerja yang bersangkutan. Pendapat Tim Intensifikasi didukung dan sejalan seperti yang disampaikan oleh petugas Kecamatan, hasil wawancara dengan petugas mengemukakan bahwa: Setiap bagian atau tim yang ditugasi Camat untuk mengingatkan dan selalu memantau atau memonitoring petugas pengelola pajak bumi dan bangunan di tingkat Kecamatan maupun di tingkat Kelurahan dan Desa.

Berpijak pada pendapat di atas dan hasil penelitian melalui observasi pada Kantor DPPKA, oleh peneliti dianalisis bahwa: aktivitas kewenangan pengarahan dilakukan dalam bentuk secara berjenjang sebagaimana telah ditetapkan melalui Keputusan Bupati dan oleh peneliti telah dipaparkan pada halaman terdahulu bahwa: (1). Kewenangan utama pengarahan pada Wilayah Kabupaten melalui Tim Intensifikasi yang dilakukan oleh Dinas Pendapatan Pengelolaan Kekayaan dan Asset Daerah. (2). Kewenangan Wilayah Kecamatan bersifat mengkoordinir penyampaian surat pemberitahuan pajak terhutang pada Wilayah Kelurahan dan Wilayah Desa. (3). Tanggungjawab penyampaian surat pemberitahuan pajak terhutang pada Wilayah tingkat Kelurahan adalah Lurah dan Wilayah tingkat Desa adalah Kepala Desa. (4). Kewenangan menetapkan petugas penyampaian surat pemberitahuan pajak terhutang, bagi petugas Wilayah Kelurahan adalah Lurah dan untuk petugas Wilayah Desa adalah Kepala Desa. Aktivitas kewenangan yang ditetapkan sebagaimana yang diuraikan sebelumnya, hasil penelitian melalui observasi bahwa: peranan pimpinan sebagai penanggungjawab wilayah kerja kegiatan implementasi kebijakan belum menjalankan tugas tanggungjawab secara baik dan memuaskan, hal ini diperlihatkan dengan masih lemah koordinasi serta lemah konsistensi dalam 
implementasi kebijakan, seperti kekeliruan penerbitan surat pemberitahuan pajak terhutang kepada wajib pajak. Berbagai wilayah tingkatan dalam implementasi kebijakan memerlukan terlibatan berbagai pihak dan berbagai lembaga pemerintah sebagai implementor yang mempunyai keahlian dan keterampilan secara professional. Keterlibatan berbagai instansi kerja hendaknya didukung dengan aktivitas koordinasi dan komunikasi. Melalui koordinasi dan komunikasi diharapkan mampu meningkatkan hubungan kerja serta dapat menghindari berbagai penafsiran yang berbeda atau penafsiran yang berlawanan arah dari maksud dan tujuan diimplementasikan kebijakan. Interpretasi atau penafsiran terhadap pengarahan program kegiatan kebijakan yang akan diimplementasikan menghendaki adanya konsistenan akan tujuan program kegiatan dengan kenyataan dilapangan.

Konsistenan akan tujuan dan kenyataan di lapangan dalam implementasi kebijakan pemungutan pajak bumi dan bangunan, tampaknya terjadi kurang konsistenan pada penetapan nilai jual objek pajak oleh pemerintah Kabupaten, dimana penetapan tersebut belum sesuai dengan kenyataan di lapangan, yakni ada penetapan nilai jual pajak besar tetapi dilapangan sebenarnya harus kecil dan sebaliknya. Sehingga wajib pajak yang beban pajaknya besar ada kecendrungan timbul rasa kemalasan tidak mau membayarkan pajaknya. Hal senada dengan argumentasi petugas Desa, konfirmasi dengan petugas Kelurahan bahwa; konsistenan tujuan dengan kenyataan di lapangan, hasil wawancara dengan petugas Kelurahan menyatakan bahwa: Belum dapat dipenuhi, karena selama ini apa yang menjadi hambatan di lapangan belum pernah ditindaklanjuti oleh pihak Kabupaten dan Kecamatan, misalnya pemutahiran data dan pengumpulan surat tanda terima setoran.

Pendapat petugas Kelurahan dan petugas Desa di atas, dapat disimpulkan bahwa ketidakkonsistenan dalam mengimplementasi kebijakan pemungutan pajak bumi dan bangunan adalah terletak pada belum dilakukan pemutakhiran data wajib pajak dengan pengumpulan surat tanda terima setoran di tingkat Kelurahan dan di tingkat Desa. Interpretasi atau penafsiran dalam implementasi kebijakan dapat berlangsung efektif, perlu proses pengkomunikasian petunjuk-petunjuk pelaksanaan yang konsisten. Bila terjadi inkonsistensi informasi, maka mempersulit para pelaksana menjalankan tugasnya. Selain itupun akan mendorong mereka mengambil tindakan yang sangat longgar dalam menafsirkan implementasi kebijakan, sehingga oleh pihak-pihak yang terlibat, dapat menyebabkan ketidak-keberhasilan dalam mengimplementasikan kebijakan itu.

Berkenaan dengan penting interpretasi atau penafsiran dalam implementasi kebijakan sebagaimana yang telah dikemukakan oleh Jones (1991:321) dan oleh peneliti telah dijelaskan pada tinjauan pustaka bahwa; penafsiran adalah proses kedua setelah organisasi, yaitu interpretasi atau penafsiran adalah yang berperan penting mewujudkan keberhasilan dalam mengimplementasi suatu kebijakan. Sejalan dengan pendapat Jones di atas, tentang penafsiran menurut Davis dan Newstrom (1993:157) menyatakan bahwa: Penafsiran sesuatu symbol merupakan dasar dalam pembuatan kesimpulan yang sangat penting dalam kehidupan komunikasi dan penafsiran sebagai kegiatan komunikasi. Penafsiran dalam implementasi kebijakan yang tepat merupakan langkah awal yang berhasil. Oleh karenanya penafsiran sebagai usaha untuk mengerti apa dimaksud oleh pembentukan kebijakan dan untuk mengetahui betul apa dan bagaimana tujuan akhir itu diwujudkan. Pendapat Davis dan Newstrom di atas, menggambarkan bahwa langkah awal dalam implementasi kebijakan yang berhasil ditentukan dengan penafsiran yang tepat, dan penafsiran yang tepat harus dilakukan melalui proses komunikasi. Dengan demikian seorang petugas yang mampu menjalankan tugas terimplementasikan kebijakan harus memiliki banyak informasi sehingga penafsiran yang bersangkutan akan menjadi lebih baik dan benar.

Interpretasi atau penafsiran dalam implementasi kebijakan harus sama dari berbagai pihak yang terlibat, karena setiap kebijakan sebagai 
suatu program kegiatan melibatkan banyak orang dan membutuhkan keterlibatan dari berbagai pihak, baik dari pihak pembuat kebijakan, pihak pelaksana maupun pihak yang menjadi sasaran dari kebijakan yang diimplementasikan. Edward III dikutif dalam Winarno (2002:131) menyebutkan: "Tiga hal yang menentukan efektifitas komunikasi kebijakan, yaitu transmisi, kejelasan dan konsistensi". Transmisi sebagai proses komunikasi yang mampu menimbulkan berbagai penafsiran, adalah bahwa transmisi terdiri atas beberapa hambatan yang timbul dalam mentransmisikan petunjuk-petunjuk implementasi, yaitu: pertama pertentangan pendapat para implementor terhadap ukuran-ukuran dasar atau tujuan kebijakan, kedua: rantai birokrasi yang panjang, ketiga: persepsi selektif dan ketidakmauan para pelaksana untuk mengetahui ukuran-ukutan kebijakan. Kejelasan, yaitu: materi atau informasi mengenai tujuan dan ukuran dasar kebijakan serta pengkomunikasiannya harus jelas. Ketidakjelasan dalam mengkomunikasian petunjuk-petunjuk kebijakan akan mendorong terjadinya penafsiran yang salah. Konsistensi, yaitu berkaitan dan berhubungan dengan keragaman standard dan tujuan serta perintah-perintah implementasi yang akan memberikan interpretasi yang sama.

Interpretasi atau penafsiran yang tidak konsisten tentang tujuan suatu kebijakan akan menimbulkan kesulitan dalam rangka mengetahui dan memahami secara lengkap suatu proses implementasi kebijakan. Penafsiran dapat mempengaruhi tingkat pemahaman dan kemauan dalam implementasinya. Untuk itu dalam implementasi kebijakan menuntut agar para implementor memiliki pengetahuan khusus tentang sesuatu yang menjadi tugas pekerjaannya, agar implementasi kebijakan dapat mencapai tujuan yang diinginkan. Implementasi kebijakan berlangsung dengan ditujukan apakah keberadaan interpretasi atau penafsiran masih mencukupi atau tidak. Penafsiran yang berbeda-beda sering menimbulkan perdebatan, dan apabila diolah dengan bijaksana, maka perdebatan ini nantinya akan melahirkan suatu kebijakan baru atau program baru.
Berdasarkan pendapat para ahli tersebut dan realita di lapangan bahwa: aspek interpretasi yang meliputi: program kegiatan dalam implementasi kebijakan pemungutan pajak bumi dan bangunan, hasil studi dokumen di ketahui bahwa; kebijakan terinci dengan baik dan tanggungjawab tersebar. Pemahaman petugas belum maksimal dan bahkan petugas salah menerbitkan surat pemberitahuan pajak terhutang. Hasil observasi dapat dijelaskan bahwa program kegiatan dalam implementasi kebijakan yang ditetapkan, oleh petugas sebagai tugas tambahan. Temuan peneliti adalah program kegiatan dalam implementasi kebijakan terdapat kelemahan validasi data wajib pajak. Oleh karena itu solusi yang dilakukan adalah pimpinan sebagai penanggungjawab wilayah kerja pemungutan pajak bumi dan bangunan harus memiliki akurasi data wajib pajak serta menyediakan petunjuk teknis kegiatan bagi petugas Kelurahan dan petugas Desa. Pengarahan yang dapat diterima dan layak dilaksanakan oleh petugas, berdasarkan hasil penelusuran studi dokumen diperoleh gambaran bahwa: pengarahan tersebut belum didukung dengan ketersediaan petunjuk teknis untuk petugas dilapangan, sehingga pemahaman petugas masih rendah bahkan tidak memahami mekanisme perhitungan dan penetapan beban objek pajak. Kemudian hasil observasi dapat dijelaskan bahwa: dalam pengarahan program kegiatan dalam implementasi kebijakan bagi petugas Kecamatan, Kelurahan dan petugas Desa tidak dilakukan sosialisasi tentang informasi mekanisme terhadap perhitungan dan penetapan pajak bumi dan bangunan.

Temuan peneliti dapat dijelaskan bahwa: pengarahan program kegiatan dalam implementasi kebijakan kurang didukung komunikasi dari petugas Kebupaten dan petugas Kecamatan kepada petugas Kelurahan dan petugas Desa. Lemah komunikasi tersebut adalah yang bersifat arahan kerja. Kemudian bagi petugas Kelurahan dan petugas Desa memiliki keterbatasan kewenangan dalam menyelesaikan persoalan yang berkaitan 
dengan temuan petugas terhadap surat pemberitahuan pajak terhutang tidak cocok dengan nama dan alamat wajib pajak. Oleh karena itu solusi yang dilakukan adalah: petugas harus bersifat responsif serta rutin membuat dan melaporkan data wajib pajak untuk menjadi bahan evaluasi kepada KPP.Pratama dan Kantor DPPKA. Lebih lanjut KPP. Pratama dan DPPKA harus melakukan kegiatan sosialisasi tentang penetapan perhitungan perubahan beban pajak kepada petugas Kelurahan, petugas Desa dan kepada wajib pajak, serta DPPKA dan KPP. Pratama dipandang perlu melakukan evaluasi data wajib pajak dalam rangka menyediakan informasi data base wajib pajak yang akurat. Aspek interpretasi atau penafsiran sebagaimana yang telah dipaparkan sebelumnya,oleh peneliti dapat dianalisis sebagai berikut:

(1). Aspek interpretasi atau penafsiran tentang program kegiatan dalam implementasi kebijakan pemungutan pajak bumi dan bangunan yang telah sesuai dan telah dilakukan dengan baik adalah: (a). Informasi program kegiatan implementasi kebijakan telah didukung melalui Surat Keputusan Bupati dan Surat Edaran Perintah Tugas. (b).Ketentuan tanggungjawab dalam implementasi kebijakan penyampaian surat pemberitahuan pajak terhutang. (c).Ketentuan usaha maksimal dalam implementasi kebijakan pemungutan pajak bumi dan bangunan dengan istilah gerakan sapu sisir. (d).Ketentuan standar ukuran dasar pencapaian implementasi kebijakan bahwa realisasi penerimaan menimal 75\% (tujuh puluh lima persen) dari target yang ditetapkan.

bentuk penetapan nilai jual objek pajak serta dasar penerbitan surat pemberitahuan pajak terhutang. (2). Aspek interpretasi atau penafsiran tentang aktivitas pengarahan program kegiatan dalam implementasi kebijakan belum didukung oleh komunikasi Tim Intensifikasi yang menyeluruh dan terpadu kepada petugas pemungut Wilayah Kelurahan dan petugas Wilayah Desa. Materi pengarahan yang disampaikan belum bersifat focus, sehingga belum menghasilkan pemahaman yang baik bagi petugas pada tingkat Kelurahan dan petugas Desa, hal ini terlihat seperti; masih terdapat kesalahan dalam menerbitkan surat pemberitahuan pajak terhutang, dan aktivitas penyampaian surat pemberitahuan pajak terhutang belum dipadukan dengan aktivitas memonitor perkembangan setoran pajak. Konsistenan ketentuan program kegiatan dalam bentuk tujuan dengan kenyataan di lapangan belum sesuai, hal itu terlihat bahwa; surat pemberitahuan pajak terhutang tidak cocok dengan data lapangan dan beban nilai objek pajak bangunan tidak sesuai dengan kondisi objek pajak yang sesungguhnya di lapangan. Berdasarkan hasil penelitian yang telah dijelaskan di atas, oleh peneliti dianalisis bahwa: aspek interpretasi atau penafsiran berupa aktivitas program kegiatan dan bentuk pengarahan informasi tugas yang harus dilaksanakan dalam implementasi kebijakan, oleh petugas tidak dilakukan secara maksimal, sehingga interpretasi atau penafsiran tersebut dalam implementasi kebijakan belum memuaskan sebagaimana yang dikemukakan oleh Jones (1984:165) dan oleh peneliti seperti yang telah dipaparkan pada bab tinjauan pustaka.

\section{KESIMPULAN DAN SARAN}

Berdasarkan hasil penelitian dan pembahasan serta analisis peneliti, kesimpulan penelitian sebagai berikut, bahwa: kenyataan di lapangan implementasi kebijakan pemungutan pajak bumi dan bangunan di Wilayah Kecamatan Sintang, yakni: Aspek interpretasi/penafsiran belum memuaskan, dan lemah komunikasi informasi kerja, aktivitas dari aspek ini terlihat program kegiatan tidak di dukung data yang akurat, petugas lemahnya memonitor perkembangan surat tanda terima setoran pajak. Pengarahan kegiatan tidak di dukung dengan petunjuk teknis. Berdasarkan kesimpulan penelitian, maka menurut persepsi peneliti bahwa; keberhasilan implementasi kebijakan ditentukan dengan aspek organisasi, interpretasi dan aspek aplikasi tidak selamanya dapat berhasil atau berjalan dengan baik, tetapi perlu dukungan aspek pendekatan struktural berupa komitmen organisasi pelaksana. Pendekatan itu dipersepsikan peneliti sebagai konsep baru, yakni:" pendekatan struktural 
berupa komitmen organisasi pelaksana sebagai salah satu faktor penting dalam mewujudkan keberhasilan implementasi kebijakan pajak bumi dan bangunan di Wilayah Kecamatan Sintang”.

Berdasarkan temuan penelitian, kajian teoritik dan kesimpulan tentang implementasi kebijakan pemungutan pajak bumi dan bangunan di Wilayah Kecamatan Sintang, peneliti mengajukan saran yang dapat dijadikan rekomendasi akademik/ saran teoritis untuk penelitian lebih lanjut dan saran praktis untuk pelaku kebijakan, seperti uraian berikut ini: Realisasi penerimaan implementasi kebijakan pemungutan pajak bumi dan bangunan di Wilayah Kecamatan Sintang dapat mencapai target dengan cara atau upaya melakukan:"pendekatan struktural berupa komitmen organisasi pelaksana" masih memerlukan pengujian lebih lanjut melalui penelitian,

\section{DAFTAR PUSTAKA}

Devas,N \& Binder,B \& Booth,A \& Davey,K \& Kelly,R.1989.Keuangan Pemerintah Daerah Di Indonesia, penerjemah Masri Maris dan Sri-Ediswasono. Jakarta:UI Pres.

Indrawijaya, I Adam. 1986.Perilaku Organisasi. Bandung: Penerbit. Sinar Baru.

\section{Irianto,Edi,Slamet.2009.Pajak Negara Dan Demokrasi Konsep dan Implementasinya Di Indonesia. Yogyakarta: Laksbang Mediatama.}

Jones, Charles O.1984.An Introduction to the study of Public Policy. Third Edition Monterey.California: Brooks Cole Publishing Company

1991.Pengantar Kebijakan Publik ( Public Policy), Penterjemah Ricky Istanto, Editor Nashir Budiman. Jakarta: Rajawali Press.

Jones, Gareth. R.1995.Organizational Theory, Text and Cases.Texas: University by Addison-Wesley Publishing Company, Inc. sehingga konsep baru yang ditemukan semakin teruji dan berkualitas dalam rangka pengembangan ilmu administrasi publik. Aktivitas aspek interpretasi/penerapan implementasi kebijakan dapat ditingkatkan melalui: Pimpinan unit kerja seperti DPPKA, KPP.Pratama, Camat, Lurah dan Kepala Desa selaku penanggungjawab kegiatan hendaknya memberikan arahan kerja kepada petugas pelaksana, didukung dengan pedoman petunjuk teknis kegiatan. KPP. Pratama dan DPPKA harus aktif mensosialisasikan kebijakan pemungutan pajak bumi dan bangunan, dan harus merespon pengajuan permasalahan dan keberatan penetapan nilai jual objek pajak. Perlu dilakukan evaluasi data wajib pajak dalam rangka penyediaan data base yang akurat.

Koentjaraningrat, 1974. Kebudayaan Mentalitet dan Pembangunan. Jakarta: PT. Gramedia.

Koordinasi Regional PBB. 1995. SekalimantanSamarinda 27 Januari 1995

Lester,James P,dan Joseph Stewart. 2000.Public Policy: An Evolutionary Approach.Second Edition.Australia: Wadsworth

Mardiasmo. 2008. Perpajakan Edisi Revisi 2008. Yogyakarta: Andi.

Pressman,JL.\& Aaron, Wildavsky.1984. Implementation How Great Expectation In Washington Are Dased In Oakland.London: California Press.

Robbins P.Stephen.1996.Jilid 2 Perilaku Organisasi Konsep-KontroversiAplikasi Edisi Bahasa Indonesia. Jakarta: PT. Prenhallindo.

1998. Jilid 1

Perilaku Organisasi Konsep- 
Kontroversi-Aplikasi Edisi Kedelapan Bahasa Indonesa. Jakarta: PT. Prenhallindo.

Saefullah,Djadja,A,H.2009.Pemikiran Kontemporer Administrasi Publik Perspektif Manajemen Sumber Daya Manusia Dalam Era Desentralisasi. Bandung: LP3AN FISIP UNPAD.

dan Praktek. Yogyakarta: Graha Ilmu.

Soemitro,R. 1989. Pajak Bumi dan Bangunan, Bandung :PT Eresco.

Suparmoko. 2000. Keuangan Negara teori dan Praktek, Edisi lima, Yogyakarta: BPFE UGM.

Dokumen-Dokumen dan Peraturan-Peraturan Badan Perencanaan Pembangunan Daerah dan Badan Pusat Statistik Kabupaten Sintang, Kabupaten Sintang Dalam Angka Tahun 2010. Sintang: Sekda. . Kecamatan Sintang Dalam Angka Tahun 2010. Sintang: Sekda.

Kantor BPKKD Kabupaten Sintang. 2009. Tentang Pokok dan Tunggakan PBB Sektor Perkotaan dan Pedesaan tahun 2009. Sintang: Sekda.

Kabupaten Sintang Bappeda.2005.Tentang Rencana Pembangunan Jangka Menengah ( RPJM) Kabupaten Sintang tahun 2006-2010. Sintang: Sekda.

Keputusan Menteri Pendayagunaan Aparatur Negara Republik Indonesia Nomor:63/ KEP/MPAN/7/2003.Tentang pedoman umum penyelenggaran pelayanan publik.Jakarta: Kepmenpan.

Keputusan Menteri Pendayagunaan Aparatur Negara Republik Indonesia Nomor:25/ M.PAN/2/2004.Tentang pedoman penyusunan indeks Kepuasan Masyarakat Unit Pelayanan Instansi Pemerintah.Jakarta: Kepmenpan.
Keputusan Menteri Pendayagunaan Aparatur Negara Republik Indonesia Nomor:26/ KEP/M.PAN/2/2004. Tentang Petunjuk Tehnis Transparansi dan Akuntabilitas Dalam Penyelenggaraan Pelayanan Publik. Jakarta : Kepmenpan.

Keputusan Menteri Keuangan Republik Indonesia Nomor: 085/WPJ.13/BD.03/2009. Tentang Penetapan Besarnya Nilai Jual Obyek Pajak Tidak Kena Pajak Sebagai Dasar Penghitungan Pajak Bumi dan Bangunan Kabupaten Sintang. Jakarta: Depkeu.

Keputusan Bupati Sintang Nomor:18 Tahun 2002.Tentang Petunjuk Pelaksanaan tatacara penyampaian surat pemberitahuan pajak terhutang, penagihan / pembayaran serta pelaporan pajak bumi dan bangunan di Kabupaten Sintang. Sintang: Sekda.

Keputusan Bupati Sintang Nomor: 52 Tahun 2002. Tentang Penunjukan Tugas Pengelola Administrasi PBB dan Pemungut Penyetor PBB Daerah di Wilayah Kecamatan dalam Kabupaten Sintang. Sintang: Sekda.

Keputusan Bupati Sintang Nomor:834 Tahun 2008.Tentang Pembagian Penyusunan dan Pengendalian Penggunaan Insentif Pajak Bumi dan Bangunan dari Pemerintah Pusat untuk Pemerintah Kabupaten Sintang atas Pencapaian Target Pajak Bumi dan Bangunan Tahun 2007 di Kabupaten Sintang. Sintang: Sekda.

Keputusan Bupati Sintang Nomor: 1106 Tahun 2009.Tentang Pembentukan Tim Intensifikasi Pajak Bumi dan Bangunan serta Penetapan Besarnya Prosentase Biaya Pemungutan Pajak Bumi dan 
Bangunan Kabupaten Sintang Tahun Anggaran 2009. Sintang: Sekda.

Keputusan Bupati Sintang Nomor:1108 Tahun 2009.Tentang Penetapan Pengelola dan Besarnya Prosentase Insentif Pajak Bumi dan Bangunan tahun Pajak 2007 bagi Pengelola Pajak Bumi dan Bangunan Kabupaten Sintang atas Beban Anggaran Pendapatan dan Belanja Daerah Kabupaten Sintang tahun Anggaran 2009. Sintang: Sekda.

Peraturan Pemerintah Nomor:104 tahun 2000.Tentang Dana Perimbangan. Jakarta: Menkeu.

Peraturan Direktur Jenderal Pajak Nomor:6/PJ/ 2008.Tentang Tata cata Pengurangan Denda Administrasi Pajak Bumi dan Bangunan. Jakarta: Dirjen Pajak.

Peraturan Bupati Sintang Nomor: 2 Tahun 2007.Tentang Petunjuk Pelaksanaan Tatacara Penyampaian Surat Pemberitahuan Pajak Terhutang , Penagihan /Pembayaran serta Pelaporan Pajak Bumi dan Bangunan di Kabupaten Sintang. Sintang: Sekda.

Peraturan Bupati Sintang Nomor:59 Tahun 2008.Tentang Pembagian dan Penggunaan Insentif Pajak Bumi dan Bangunan dari Pemerintah Pusat untuk Pemerintah Kabupaten Sintang atas Pencapaian Target Pajak Bumi dan Bangunan di Kabupaten Sintang. Sintang: Sekda.
Peraturan Bupati Sintang Nomor:15 Tahun 2009.Tentang Petunjuk Pelaksanaan Tatacara Penyampaian Surat Pemberitahuan Pajak Terhutang , Penagihan /Pembayaran serta Pelaporan Pajak Bumi dan Bangunan di Kabupaten Sintang. Sintang: Sekda.

Peraturan Daerah Kabupaten Sintang Nomor:2 Tahun 2008.Tentang Struktur Organisasi Pemerintah Daerah. Sintang: Sekda.

Pokok-Pokok Penyelenggaraan Pemerintahan Umum Republik Indonesia, Dirjen Pemerintahan Umum Tahun 2004. Jakarta: Dirjen PUOD.

Undang-Undang Repbulik Indonesia Nomor:28 Tahun 2009.Tentang Pajak Daerah dan Retribusi Daerah. Jakarta: Novindo Pustaka Mandiri.

Undang-Undang Republik Indonesia Nomor:32 Tahun 2004.Tentang Pemerintah Daerah.Jakarta: Restu Agung.

Undang-Undang Republik Indonesia Nomor: 33 Tahun 2004. Tentang Perimbangan Keuangan Antara Pemerintah Pusat dan Daerah, Jakarta: Restu Agung.

Undang-Undang Republik Indonesia Nomor:12 Tahun 1994.Tentang Pajak Bumi dan Bangunan. Jakarta: Dirjen.Pajak. 